\title{
Hanging in Chains
}

A total of 144 individuals were executed then gibbeted in Britain under the Murder Act (1752-1832). Also known as 'hanging in chains', gibbeting was a spectacular post-mortem punishment whose impact far exceeded the relatively small number of criminal corpses that were suspended between earth and sky to be displayed for days, weeks, months, years and even decades. Sarah Tarlow has written comprehensively on The Golden and Ghoulish Age of the Gibbet in Britain, including the use of this form of post-mortem punishment before the advent of the Murder Act and its use by the Admiralty. ${ }^{1}$ Here we take a more specific temporal and judicial focus, using the Murder Act to frame our examination of the formalised use of the gibbet by civil authorities in Britain from 1752-1834. ${ }^{2}$ We begin with a description of gibbeting in Britain as a practice and process involving specific technologies, people and places. We then move on to tell three gibbet stories: William Jobling in Jarrow (1832), Spence Broughton in Sheffield (1792), and Marie-Josephte Corriveau, who was gibbeted overseas under British law (1763). The stories of the punishment of Jobling, Broughton and la Corriveau (as she is known) under the Murder Act told in this context and constructed through historical sources, archaeological evidence, and narratives, reveal complex social perceptions of what it meant to be considered 'criminal', and how the bodies of criminals were treated in relation to the interests of the state. The experiences of these three condemned prisoners, and the crowds, officials, and other actors involved in their execution and post-mortem punishments, complicate straightforward 'common sense'

(C) The Author(s) 2018

S. Tarlow and E. Battell Lowman, Harnessing the Power of the Criminal Corpse, Palgrave Historical Studies in the Criminal Corpse and its Afterlife, https://doi.org/10.1007/978-3-319-77908-9_6 
narratives of deterrence and justice in eighteenth- and nineteenth-century crime and punishment, as we set out in Chapter 1. Finally, this chapter considers the legacy of the gibbet in Britain, including the power this punishment and these criminal corpses held, but also the ways in which the gibbet was part of globalising processes of carcerality and punishment through its use in Britain's overseas holdings during the period of the Murder Act.

The last gibbeting in Britain took place in the summer of 1832, after the passage of the Anatomy Act appeared to some judges to leave hanging in chains as the only available option for murder convictions. Before 1832, the gibbet had largely fallen out of use in nineteenth-century Britain. Following a public outcry, it was taken off the books in 1834. Though nearly 200 years have since passed, representations of hanging in chains arise often in Britain and North America. Whether in popular film and television or Halloween decorations, gibbets seem to be more common in the imagination of entertainment media than they ever were in real life. Media portrayals of gibbeting can be found in several major motion pictures, such as the cage in which Robin Hood's father was punished and died in Robin Hood: Prince of Thieves (1991), or the pirate skeletons Captain Jack Sparrow passes swinging in the wind during the opening scene of Pirates of the Caribbean: The Curse of the Black Pearl (2003). ${ }^{3}$ They are also common in literature, whether in various nonfiction representations of Tudor history, or in lighthearted fantasy novels - gibbets even exist in Terry Pratchett's Discworld where they follow the form used and serve similar purposes as in eighteenth- and nineteenth-century Britain. ${ }^{4}$ Museums and attractions where original and replica gibbets are displayed, including the medieval Guildhall in Leicester continue to attract those with a curiosity for ghoulish local histories nearly two centuries after the practice was abolished in Britain (Fig. 6.1). Undeniably, the gibbet is still with us, and continues to loom large in popular imagination.

Our contemporary beliefs and the historical realities of the gibbet are not always aligned, however. Under the Murder Act, gibbeting became a much more complex practice than these various later representations normally portray, in terms of both the legal procedures leading to the punishment, and the requirements of the physical process. Involving purpose-built structures for the suspension and display of hanged criminals, gibbeting was more art than science. The eighty-year period of the Act never saw the emergence of a clear consensus on best practices, either in the judicial realm or in the material matter of constructing the gibbet itself. First and foremost, contrary to some pop-culture portrayalsincluding the popular 1988 fantasy film Willow, in which Madmartigan 
Fig. 6.1 Replica of James Cook's gibbet cage of 1832 , now in Leicester guildhall (Sarah Tarlow)

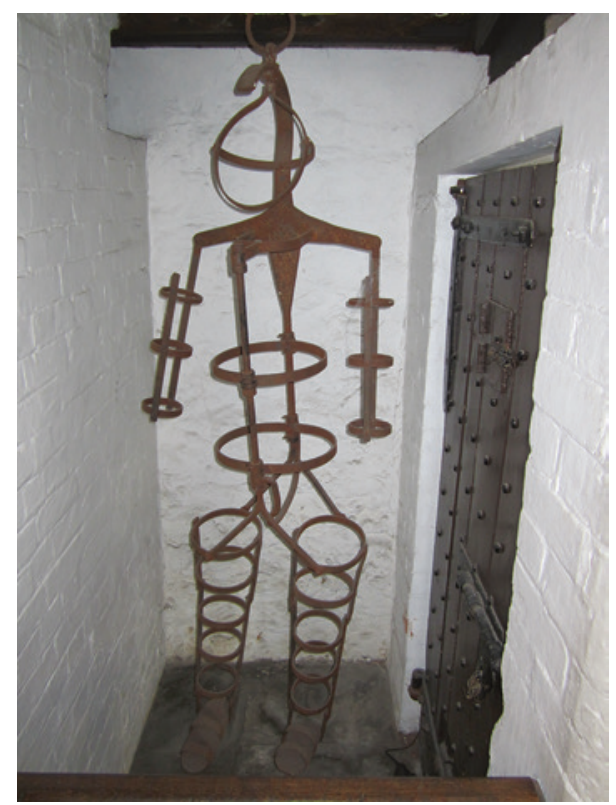

first appears on screen imprisoned in an iron cage suspended in the aironly the dead were hung in chains in Britain in the eighteenth and nineteenth centuries. ${ }^{5}$ In accordance with the Act, convicted criminals were first hanged by the neck until dead, and then their lifeless body was suspended on the gibbet. Of the 144 individuals gibbeted under the Act in Britain, we have identified no women, and all evidence seems to confirm that in this period only men were gibbeted. ${ }^{6}$

As a punishment, like post-mortem dissection and anatomisation discussed in Chapter 5, gibbeting was intended to inspire terror among witnesses and onlookers. It involved suspending the corpse of a convicted murderer between earth and sky, thereby exiling the criminal body to a liminal space, and leaving it there for up to several decades until there was little, if anything, left. For the condemned, sentencing made them aware that their body would be denied proper burial, and would be exposed, subject to public scorn, and would visibly decay, drop and be devoured by animals and insects. The criminal body might be further subjected to the ignominy of being stolen or carried off - at times, piece by piece-as decay allowed bones to fall through the gibbet cage onto the ground. In other cases, decay left an assemblage of bony body parts 
Fig. 6.2 John Breads's skull survives within the cage of his gibbet at Rye (Sarah Tarlow)

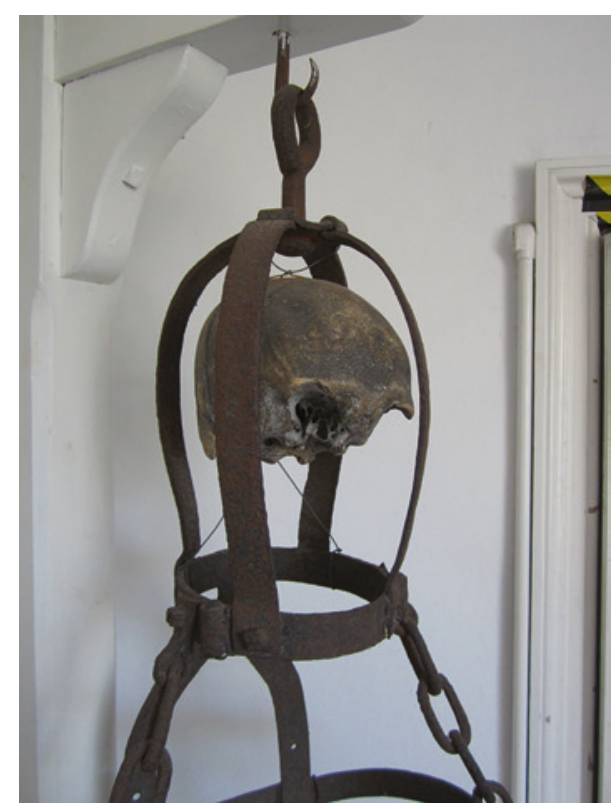

in the cage from which they could not be easily extracted (especially skulls, the only bones which were unlikely to fit through the cage without assistance $)^{7}$ (Fig. 6.2). Certainly there was no peaceful 'rest' to anticipate that might ease a troubled mind before execution.

Gibbeting was also intended as a deterrent to the commission of heinous crimes by others: it was expected to, and often did, inspire horror, terror and revulsion in onlookers through the denial of funeral rites and desecration of the corpse. The humiliating display of the body, its eerie and uncanny motion on the gibbet, and the disgusting smells and excretions emanating from the corpse as it decomposed, all contributed to this spectacular, arresting punishment. And insofar as the decaying bodies of gibbeted criminals served to enforce the law through fear, the gibbet was also a key factor in asserting state power through social horror.

These generalities aside, however, the historical life of the gibbet is diverse and complex. We speak of 'the gibbet' as if it was a single, straightforward object, but the term is actually simple shorthand for a complex nexus of techniques and technologies. ${ }^{8}$ That is to say, there was a great deal of variation in how the material gibbet was produced and used, and these differences are important for the kinds of social 
discourses that sprang up around the occasion and location of gibbeting, whether those in support of state power, in sympathy for the condemned men, or otherwise. Making sense of the range of gibbet techniques and technologies employed under the Murder Act requires extensive comparison which is enabled by the compilation by the Criminal Corpse team of a list tracing as many surviving material remains of and textual allusions to gibbets as possible.

\section{Wood, Metal, Land and Flesh: Making Gibbets}

There are three types of evidence that, taken together, have made it possible for us to undertake an entirely unprecedented engagement with one of the most evocative but understudied forms of punishment in British history. ${ }^{9}$ First, sheriffs in eighteenth- and nineteenth-century Britain were responsible for organising the construction and erection of the gibbet, engaging guards to provide security at the gibbet site, and overseeing the corpse's progress from gallows to gibbet. The Sheriffs' Cravings are the detailed reimbursement claims for the costs sheriffs incurred in the course of carrying out this punishment. ${ }^{10}$ Investigated for the Criminal Corpse project by historian Richard Ward, ${ }^{11}$ this hitherto underused source lists in fine detail the materials and services required to gibbet a man under the Murder Act. Second, archaeologist Sarah Tarlow conducted a comprehensive survey of all existing gibbet cages (the part that encases the body) in Britain today, and was able to identify 16 whole or partial cages, allowing for unprecedented comparative analysis. ${ }^{12}$ Third, work with textual sources including newspapers, pamphlets, broadsheets, ballads and images provided valuable information on the spectacle and sociopolitical role of the gibbet in Britain. By combining information from these sources, it has been possible to construct an accurate idea of the gibbet as built and used by civil authorities during the life of the Murder Act. ${ }^{13}$

All British gibbets share common features and yet are also unique. They are perhaps best understood as variations on a core theme, in which a number of different factors played into the creation of the individual forms. We have identified six distinct elements that comprise all gibbets used during our period of study: a corpse, metal cage, hook and/ or short chain, crossbeam, post and erection site. Each of these features can vary in any number of ways while still fulfilling their function as part of the gibbet assemblage. We turn here to a close examination of each element, beginning with the erection site. 
156 S. TARLOW AND E. BATTELL LOWMAN

(a)

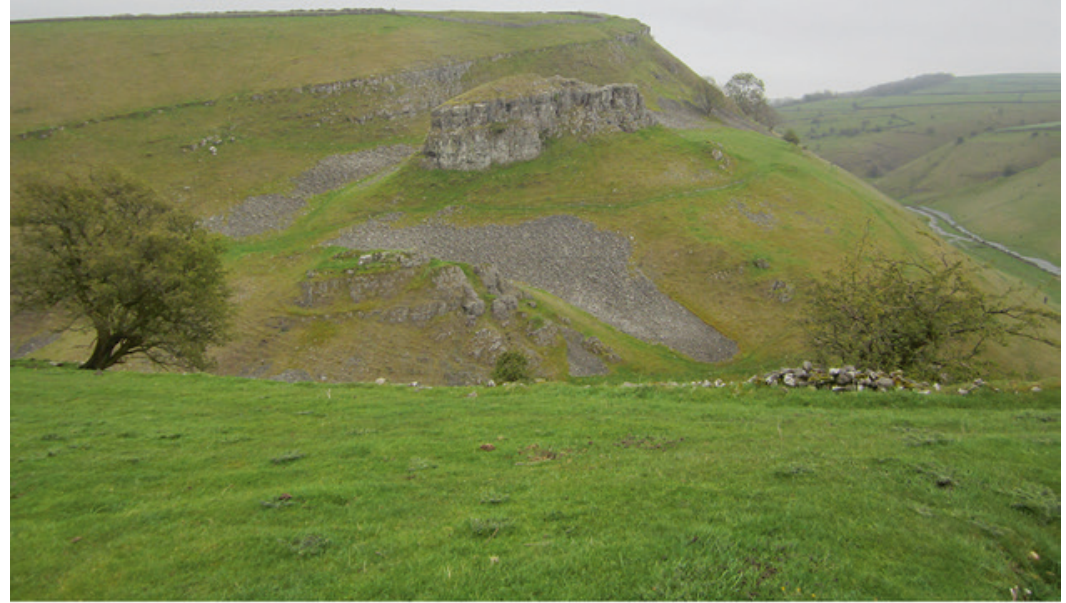

(b)

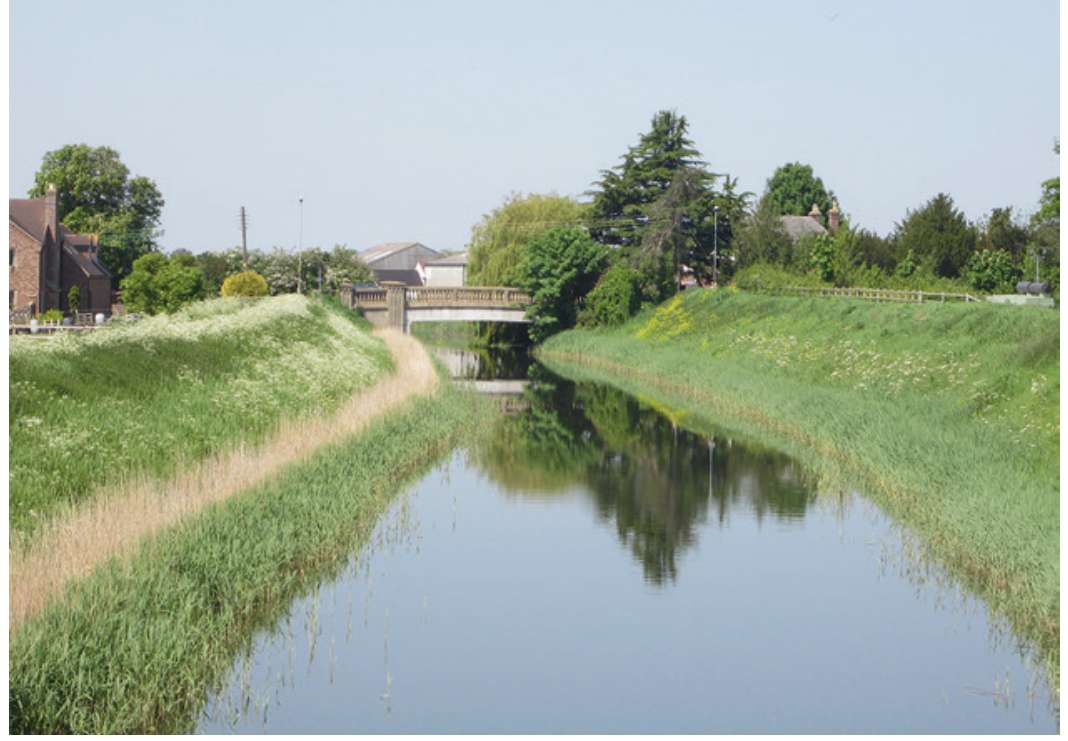

Fig. 6.3 (continued) 


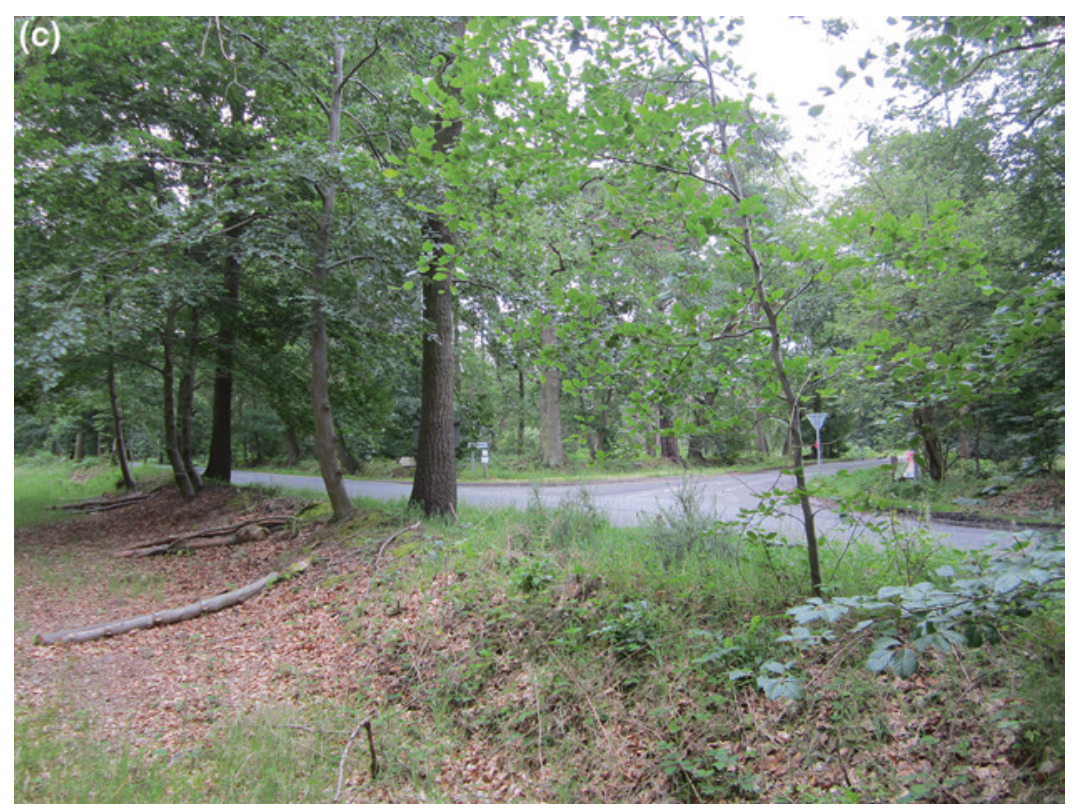

Fig. 6.3 Gibbet locations. a St. Peter's rock, Derbyshire, Anthony Lingard's gibbet took advantage of this natural landmark. $\mathbf{b}$ A gibbet sited on the riverbank in Sleaford took advantage of its visibility from both the road and the river. $\mathbf{c}$ Abraham Tull and William Hawkins were gibbeted near this crossroads in Berkshire (all photographs: Sarah Tarlow)

Place is important to the function of gibbets, and spatial considerations of the gibbet are a key element of this technology. Gibbet sites were carefully selected and often the sentencing judge indicated a general space or site in the sentence, sometimes one relating to the crime committed by the condemned prisoner. Many were erected at or near the location of the crime, the trial, or other aspect of the judicial proceedings. ${ }^{14}$

However, the gibbet could not be located at the scene of the crime without consideration of other, more practical concerns (Fig. 6.3). Key to site selection was the need for both security and accessibility. Like hangings, gibbetings and the gibbet itself drew large crowds. It was not unusual for thousands, and sometimes tens of thousands, of people to visit new gibbets, and they remained sites of interest and visitation so 
long as the gibbet stood. Limited access combined with large crowds risked property damage, riots, and other dangers of large-scale disorder. In addition to allowing sufficient space to accommodate the curious and carnivalesque crowd, the site needed to help ensure the visibility of the gibbet. High places such as hills or locations next to major travel routes or at crossroads were all sites that accomplished this goal. Locations such as on commons, wasteland or open heath also allowed large crowds to gather safely. ${ }^{15}$ A final consideration in selecting a gibbet site was managing the sensory experience of the gibbet, by which we mean that a body in various states of decay gives off a variety of pungent and deeply unpleasant smells while also being distinctly visually unappealing. Officials were sometimes petitioned to relocate gibbets located near the homes or properties of prominent individuals, requiring additional work and expense. The gibbets of Abraham Tull and William Hawkins in Berkshire were taken down and buried at the request of a well-to-do local lady. William Andrews recorded that 'Mrs. Brocas, of Beaurepaire, then residing at Wokefield Park, gave private orders for them to be taken down in the night and buried, which was accordingly done. During her daily drives she passed the gibbeted men and the sight greatly distressed

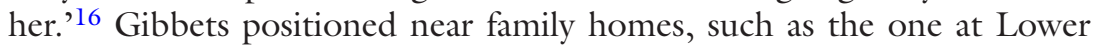
Hambleton, now submerged beneath Rutland Water, contributed to enduring guilt and infamy being attached to not just the convict, but also their surviving kin. ${ }^{17}$ In that case the parents of the two brothers suspended there could see their sons' remains from their front door.

Gibbet locations were chosen both because of the existing physical landscape, and also because of the social and cultural landscape that became entangled with these unmistakable, grisly objects. Their semi-permanence, the attention they drew from local people and visitors, and the stories of the crimes of the gibbeted individual (see Chapter 8) transformed these sites and changed their relationships to nearby places and the people who passed through-just as the site impacted the longevity and social impact of the gibbet.

Moving from site to structure, gibbets were erected by first securing a sturdy post in the ground. Thus, tethered to and drawing strength and stability from the earth, gibbets were constructed to stand for years, decades, or longer. The gibbet required a thick wooden beam, about 10 metres long that was planted firmly in the ground-in at least one case, secured there with a foundation stone-so that it stood upright. ${ }^{18}$ The post had to be strong enough to support the weight of the crossbeam 
and heavy iron gibbet cage year-round for an indefinite period. The height of the post had to be great enough to make the swinging body visible from a distance. The height also helped to complicate potential efforts to rescue (or steal) the corpse, and some posts were made more secure by studding them with thousands of nails, or plating the lower part of the post in iron to make it very difficult to saw through (Fig. 6.4).

The next element of the gibbet was a wooden crossbeam (Fig. 6.5). This beam was attached near to or at the top of the gibbet post at a 90-degree angle. It had to be of sufficient length to allow the gibbet cage to be attached to the end opposite the post without resting against it. Here also, the crossbeam had to be strong enough to support the weight of the gibbet cage and body outdoors for up to several decades.

An iron hook and/or short length of chain were the means by which the cage was attached to the crossbeam and suspended in the air.

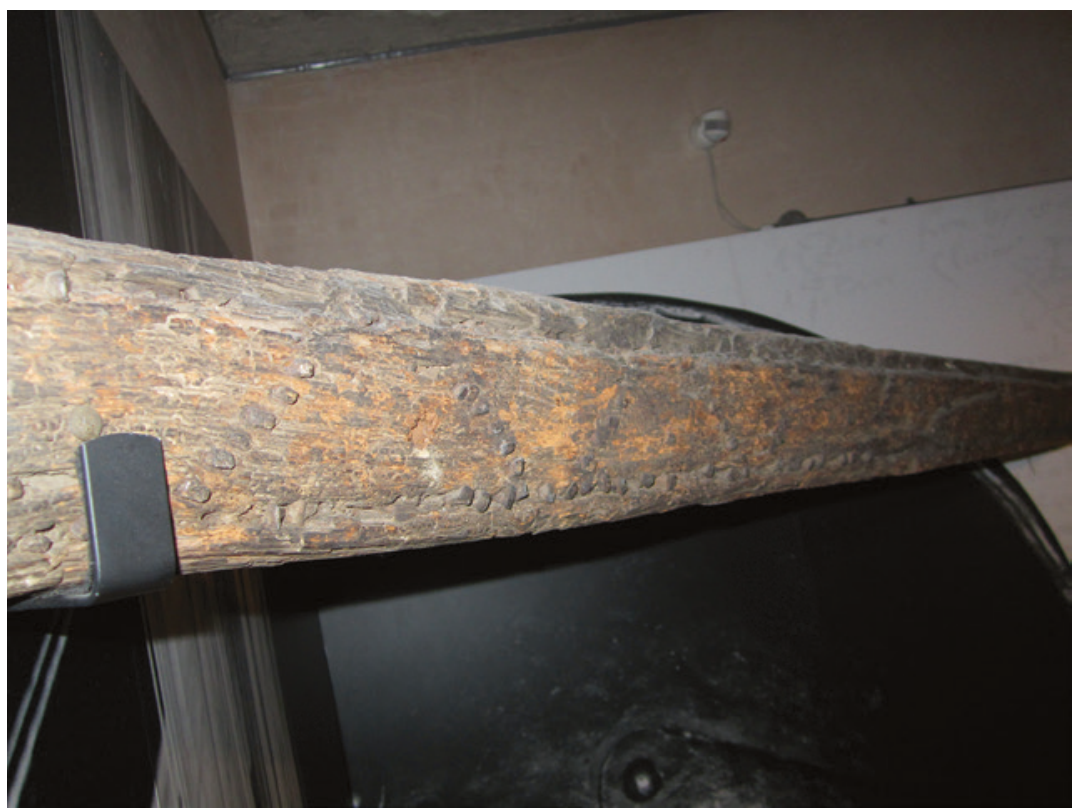

Fig. 6.4 Post of a gibbet (possibly Parr's) with nails used to reinforce it and make it harder to saw through, now in Banbury Museum (Sarah Tarlow) 


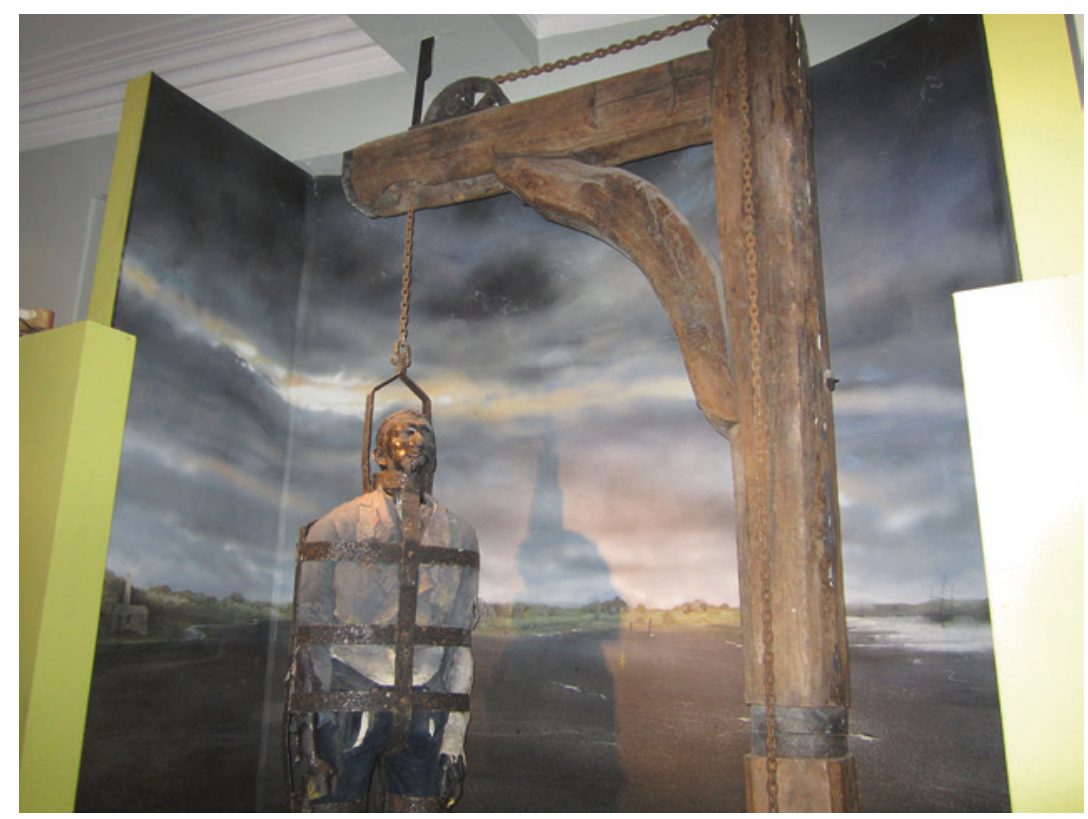

Fig. 6.5 The crossbeam of a gibbet allowed the caged body to swing freely (Sarah Tarlow)

The hook and chain, like the post and crossbeam, had to be sturdy enough to support the weight of the cage and corpse long term. However, a critical aspect of this element of the gibbet is that, while it firmly connected the cage to the wooden structure, at the same time the hook or chain had to permit the cage to move - that is, to swing or rotate freely. The gibbet cage of John Breads (executed in 1743 for the murder of his brother-in-law, Allen Grebell) held in the Rye museum, Sussex, shows the sort of device that was used to attach the cage to the crossbeam. The metal of the top of the hook is visibly worn down on the Rye gibbet, demonstrating not only that movement of the suspended cage occurred, but that the cage experienced significant and regular movement during the more than 20 years that Breads' gibbet stood in Gibbet Marsh (Fig. 6.6). Movement played a key role in the way that the public experienced gibbets. As the wind caused the gibbet to sway, the metal-on-metal sound of the hook and chain caused an eerie noise that was especially unsettling at night. ${ }^{19}$ 
Fig. 6.6 Hook of

Breads's gibbet, Rye, showing wear (Sarah Tarlow)

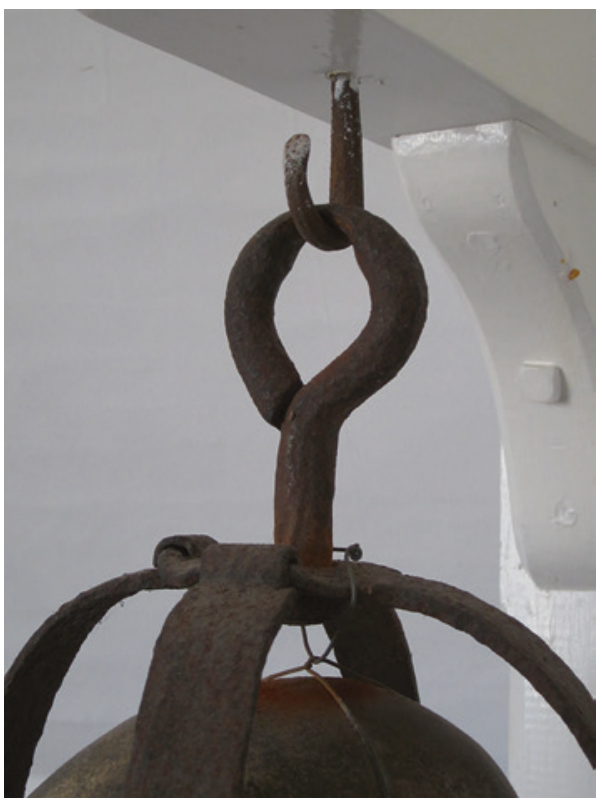

The cage is the most visually arresting element of the gibbet. Though the punishment was also known as hanging in chains, the gibbets used by civil authorities during the life of the Murder Act did not wrap the body in chains, but rather encased it in a purpose-built cage made of inflexible iron bands. These held the body securely and the cage was attached via the hook and/or chain to the crossbeam. Even empty, its shape continued-and continues - to evoke the body it once held (or would hold). There are a variety of gibbet cages on record, most of which were shaped to both contain the body of the criminal, and to evoke the human form even after the body decayed. Tarlow has found from her work with the 16 extant examples in Britain, that there is considerable variation in the form and construction of gibbet cages, and no local design traditions can be observed. ${ }^{20}$ However, the similarities between these artefacts reveal important components in their construction and use under the Murder Act. First, the cage of the gibbets held its occupant in an upright (standing) position. Though this could be accomplished with supports under the crotch and sometimes under the feet, and an articulated head piece to hold the body in this position, a key factor in accomplishing this is 
Fig. 6.7 Keal's gibbet, Louth Museum, only encloses the head and torso (Sarah Tarlow)

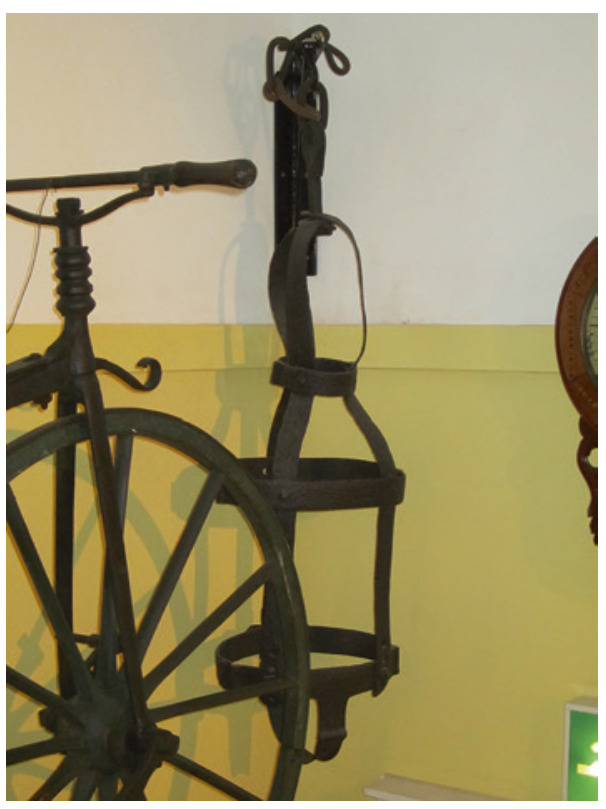

that cages were invariably suspended from the crossbeam by attaching the hook and/or chain to a point at the top of the head. Second, it held the body securely so that it could not be easily removed or slip free. As is visible in Keal's gibbet at Louth, Lincolnshire, the bands were cinched tight around the torso and other large body parts (Fig. 6.7). Cages invariably encased the torso and head, though some also had bands to secure the arms and legs. That the cage had to fit tightly to the body in order to constrain it is what gave rise to its anthropomorphic form (Fig. 6.8). Third, the cage allowed physical and visual access to the body. The iron bands could not be so thick as to completely obscure the corpse. Rather, the cage had to permit the visibility and recognisability of the body. This aspect of the gibbet also allowed animals, birds and insects access to the swinging corpse, encouraging decay and disintegration of the body. The cages used as part of punishment under the Murder Act were single-use items and there is no evidence to suggest they were reused. Rather, like the other parts of the gibbet, the cage was intended to be sturdy enough to secure the body and last for decades exposed to the air and elements. 


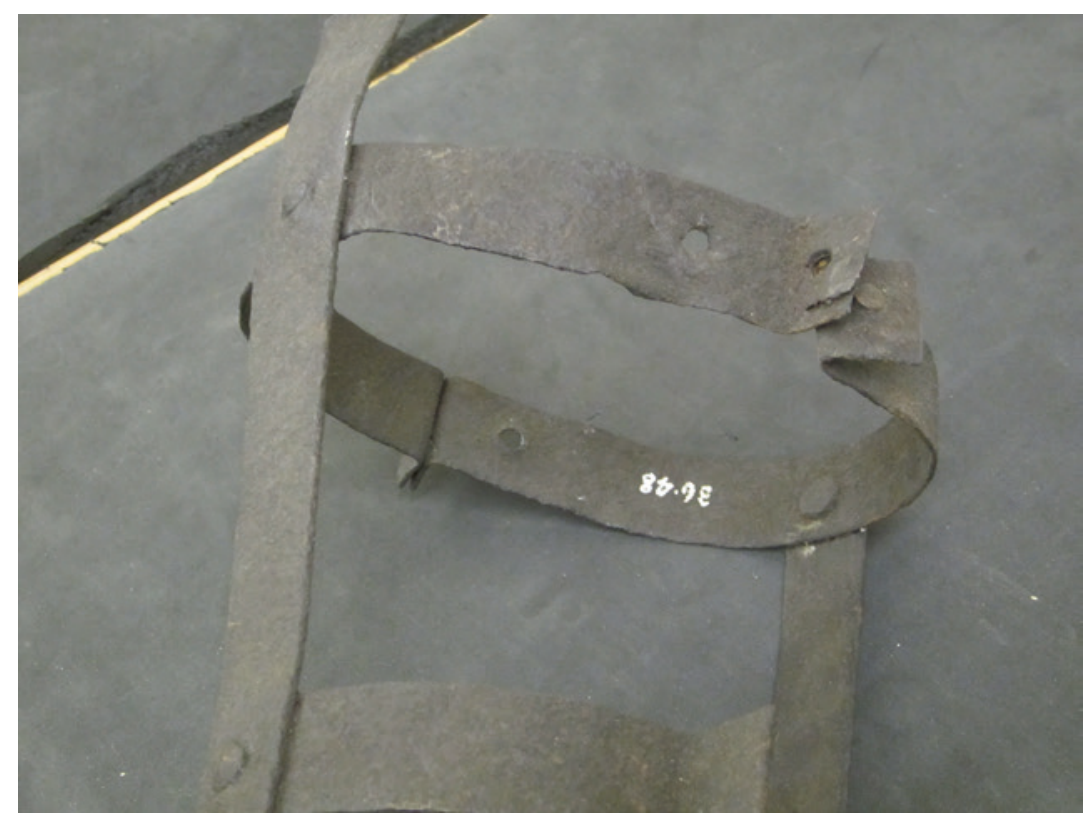

Fig. 6.8 Punched holes on the gibbet allowed adjustment to fit the body of the criminal (Sarah Tarlow)

The standing position and anthropomorphic shape of the cages contributed to two important and eerie effects of the gibbet. First, that the body in the gibbet so clearly dead-since this was an expressly post-mortem punishment and local people were very likely to have witnessed the execution-seemed somehow and unnervingly alive. The standing position, the swaying, swinging, or turning in the wind, all created an uncanny and paradoxical impression of 'life'. Further, as a body decayed, was consumed, or pieces dropped to the ground, the cage might become empty, bit by bit. The absence of the body, however, in the continuing presence of the swinging, turning, man-shaped cage only reinforced the unsettling nature of the punishment.

The final element of the gibbet is the corpse, which is literally and figuratively at the centre of this form of post-mortem punishment. As mentioned, civil authorities (unlike the Admiralty courts) did not reuse gibbets, which created a one-to-one relationship between a particular 
corpse and its gibbet. This meant a gibbet could be referred to by the name of the criminal it held or by its location with ease and specificity. The corpse was brought by cart from the place of execution, which might be near to or identical with the selected gibbet site, as discussed above. A good example of this is the case of John Walford, who was gibbeted in 1789 at the scene of his execution in the Quantock Hills of Somerset. In contrast, criminals executed by the Admiralty might be transported some distance from the site of execution in London to the site of their gibbet in, say, Devon or Norfolk. Some secondary literature makes reference to covering the corpse in tar or pitch, ${ }^{21}$ as in the case of Tom Otter whose body was said to have been covered in a layer of pitch before being reclothed, presumably to aid with identification, and enclosed in the gibbet cage. However, there is no evidence of such a practice in the Sheriffs' Cravings even though small and inexpensive items, such as ale for the guards or rope for a noose, are frequently listed. Further, as the cage was designed to be form fitting, a thick layer of pitch might have caused difficulties for properly placing and securing the corpse. It is unclear, in any case, what the purpose of the pitch might be since there was clearly no desire to try and preserve the body. Rather, once the body was sealed into the cage, it was unlikely ever to be removed from it except in the course of progressive decay-a key element to the horror of the gibbet intended to deter future crimes.

\section{Progress and Punishment: Did the Gibbet Work?}

In addition to the material technique of gibbeting, involving the physical elements (place, post, crossbeam, hook and chain, cage and corpse), the gibbet was and remains a product of discrete but connected discourses of punishment. For the state, gibbeting during the period of the Murder Act was intended to serve two complementary purposes. First, as Elizabeth Hurren has argued, and as was discussed in Chapters 4 and 5, the Murder Act constituted an expression of the common law principle lex talionis. Derived from Roman law, lex talionis-captured succinctly by the adage 'an eye for an eye'-refers to the reestablishment of social order following a severe transgression by inflicting upon the malefactor the harm they visited on their victim. The punishment for murder under the Act therefore stripped the murderer of their own life and debased the body as murder did to the victim, in this case by denying proper burial. Gibbeting was intended to accomplish this goal in a way both similar to 
and different from public dissection. The medical men might dissect a body to the point where it could no longer be recognised as an integrated individual, but suspension in the gibbet obliterated the body as a social object, exiling it to the liminal space between earth and sky, and did so publicly in order that the communities affected by the crime could witness that justice had been done. Second, the state intended the spectacular punishment of those who had transgressed one of the most fundamental human social laws (the unsanctioned killing of other humans) to act as a deterrent to further commission of the crime by others. The humiliating, powerless exposure and display of one's body, and the knowledge of how the impending punishment affected the condemned before death-including stories of 'hard men' such as Lambert Reading in 1775 who were unfazed by the idea of execution but could not hear the sentence of gibbeting with equanimity-were intended as an instructive lesson to the many who witnessed, read about, or spoke of the punishment. ${ }^{22}$ For the State, gibbeting was intended to restore social and State cohesion and function following a transgression, while simultaneously reducing the probability of future incidences of the crime being committed by others. For all the effort accorded these aims, how far were they actually achieved at the foot of the gibbet, or in the pages where the punishment was represented for an eager public? There is no unambiguous answer.

There were no clear guidelines within the Act regarding which post-mortem punishment a judge selected when sentencing a murderer. Both were equal in the eyes of the law. However, it is possible to discern in practice one convention and two probable factors that directed judges in their decision to choose the gibbet over anatomisation and dissection. First, as mentioned, of the 144 instances of gibbeting under the Murder Act in Britain identified by our research, we know that no women were gibbeted. They were invariably sent for anatomical dissection.' 23 The reason why female murderers were always sentenced to dissection and anatomisation rather than gibbeting in the eighteenth and nineteenth centuries is less clear. We do know that female bodies were highly sought-after by the surgeons and that this added value or demand may have swayed the decision to dissect rather than hang in chains. ${ }^{24}$ Further, as Peter King has noted, social sensitivities in Britain regarding the treatment of the bodies of executed female criminals may have extended to a general and strong reluctance to gibbet women. ${ }^{25}$ In early modern France, such chivalrous concern for decorum sometimes led to 
the refusal to execute women by hanging, preferring instead to bury them alive. ${ }^{26}$ However, as we will see, the British aversion to gibbeting women evaporated when we travelled into the overseas British world.

Beyond the issue of sex, age and availability may have played a pragmatic role in guiding judges to choose gibbeting when sentencing convicts. In cases where more than one murderer was sentenced at the same time and location, a judge might decide to split the fate of the condemned, sending some to the surgeons and some to the gibbet. In 1784 father and son John and Nathan Nicholls were both convicted of and executed for the same crime in Suffolk. The son's body was taken by the surgeons, but the older man was hung in chains, perhaps because his body was a less desirable anatomical object. A decision of this kind may have been rooted in several considerations: if surgeons in an area were unable to make use of multiple bodies (particularly at times of the year that promoted rapid decomposition) it may have been unfeasible to send the body to surgeons elsewhere, undesirable because it removed the instructive opportunity of the post-mortem punishment from the community most affected by the crime, or risky if it deprived the gallows crowd from witnessing the conclusion of the punishment spectacle. Surgeons probably made clear their practical preferences when multiple bodies were potentially available to them under the Act. Robust, young bodies were in demand for medical purposes and those of the aged or infirm, much less so. Gibbeting was much more expensive per body than anatomisation and dissection and was much more spatially intensive - the display of the anatomised body required a suitable room for a day or two, but the gibbet required an open plot of land for decades. Differential post-mortem treatments of murderers' bodies did not follow any hard and fast rules, however. Rather, judges took into consideration numerous logistical and judicial concerns when deciding which post-mortem punishment should be accorded a convicted murderer.

The ignominy of the long-term public display of the corpse as it decomposed on the gibbet, and its relative rarity compared to anatomisation and dissection, might suggest that this punishment was reserved for those who committed the most violent and shocking murders (Fig. 6.9). Certainly, beyond the Murder Act, civil authorities reserved their discretionary use of the gibbet to criminals sentenced for particular types of crimes. Those that threatened the authority of the state for all manner of treasons have a history of being subjected to post-mortem punishment, particularly the quartering of criminal corpses but also display on 
Corpses Hung in Chains under the Murder Act, 1752-1832 (including Admiralty cases)

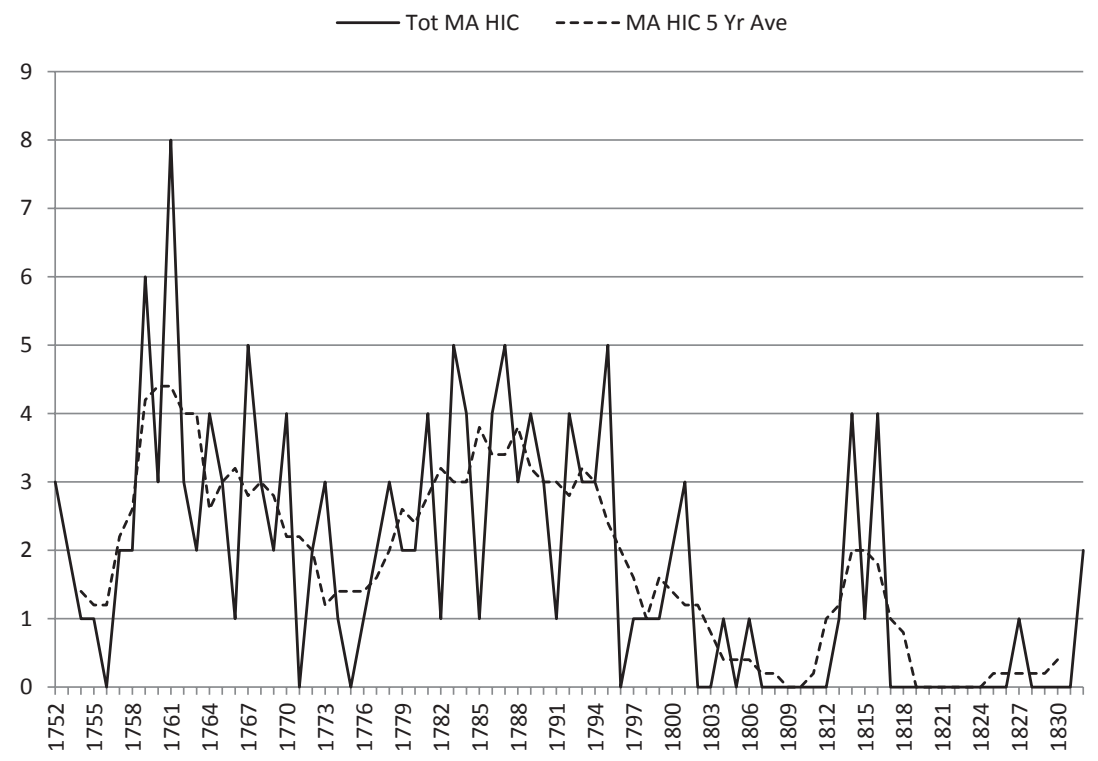

Fig. 6.9 The frequency of gibbeting from before the Murder Act to its end (Sarah Tarlow)

the gibbet. ${ }^{27}$ Robbing the post and highway robbery were also by custom punished in this way, as they were seen as crimes that disrupted the natural flow of people, information, and money-mobilities that served the interests of the state, even if indirectly. ${ }^{28}$ However, under the Murder Act there is no evidence to suggest that judges used any particular metric of the horror of a murder to determine post-mortem punishment. ${ }^{29}$ Judges worked within their understandings of the law, the sociopolitical context in which a crime and its prosecution occurred, and the parameters of practical considerations such as capacity, cost, time and impact.

And yet, gibbeting under the Murder Act seems out-of-step with prevailing understandings of the changing nature of punishment during this period. The late eighteenth century saw the rise of confinement as a specific form of punishment along with discourses of rehabilitation rather than the lex talionis approach centred on punishment and retribution. Before this, accused and convicted criminals were held in gaol awaiting 
either trial or execution of their sentence (i.e., the gallows, transportation) but only as a temporary measure. However, the interruption and discontinuation of transportation to the American Colonies in 1775, following the American Revolution, forced British authorities to rethink their punishment practices. Confinement and hard labour, first on the prison hulks moored in ports across Britain, then later in large purpose-built prisons, alongside the resumption of transportation (this time to Australia and with a more distinct colonising purpose), rapidly took root. ${ }^{30}$ Those involved with engineering the shift away from capital punishment in Britain towards confinement and the penitentiary explained their efforts as a move away from the barbarity of corporal and capital punishment. ${ }^{31}$ However, in the second half of the twentieth century, historians and sociologists re-engaged with the transition from the gallows to the penitentiary and questioned the benevolent, civilising nature of this process. Powerful explanations such as the need to meet the growing demands of the labour market, the use of confinement as a way to re-establish social control in the context of class-based unrest, and as a method of more effectively exerting sociopolitical power and control through regimes of social discipline, were all posited as driving forces. ${ }^{32}$ Most potent, however, is the narrative of the civilising process. As Elias proposed, 'civilization' is marked by 'a reduction in the use of physical violence and an increase in the intensity of psychological control.'33 The display of rotting corpses in prominent public places certainly seems to have no place in this civilising trajectory. So why did the practice continue after this shift?

In fact, gibbeting in general and more specifically under the Murder Act did decline in frequency from the end of the eighteenth century. As Tarlow has found, gibbeting by civil authorities peaked before the punishment was formalised in law when the Act went into effect in $1752 .{ }^{34}$ By 1800, gibbeting was such a rare occurrence (excluding in the Admiralty courts) that only 10 took place under the Act between 1800 and 1834 when the punishment was legislated out of existence in Britain. There were probably multiple factors in this decline, including the cost, space needed, and ever-increasing need of bodies for surgical practice and training. In the early nineteenth century, we do know that gibbeting offended the sensibilities of onlookers and communities, and that the public expression of repugnance at the continuing existence of the punishment became increasingly insistent. When the punishment was repealed in 1834, the legislation passed rapidly and with little discussion. 
This was a result both of the strong public aversion to such grisly punishments and of the fact the Murder Act had effectively been made redundant by the passing of the Anatomy Act in 1832 (see Chapter 4).

But the opposition to gibbeting in the nineteenth century is also a testament to its puissance. The gibbet transformed a body into something dreadful with power over places, stories and people. The spectacular punishment impacted individuals, families, communities and nations. Just as each gibbet was unique, so too is each story.

\section{Three Gibbet Stories}

\section{William Jobling, 1832}

$\mathrm{He}$ committed no murder, on that point both victim and accused agreed. The hand that struck the ultimately fatal blow was not that of William Jobling, but his involvement in the mortal attack on Nicholas Fairles on 11 June 1832 was never in question. The degree of his involvement was contested at trial, but under the law failure to decisively act to prevent murder carried the penalty of death on the gallows. So, in the eyes of the law at least, Jobling's execution seems to have been inevitable. He was hanged by the neck until dead on 3 August 1832 by executioner William Curry outside Durham Gaol. ${ }^{35}$

But that was not the end of Jobling's punishment. The Durham Assizes judge, Mr. Justice Parke, in accord with what he believed to be the requirements of the Murder Act, passed sentence of death on the gallows but also directed that the corpse be hung in chains. Nearly two hundred years later, Jobling's name is far from forgotten; not only for his actions in life but because of the manner of its ending and the fate of his corpse (Fig. 6.10).

To say that tensions were running high in the coalfields in northeast England in the spring of 1832 would be putting it mildly. The Great Strike of 1831 may have ended in victory for the miners and improvement in the terms of their yearly contracts ('bindings'), but the unions formed in the course of that conflict that were so critical to the strike's success became the object of ire for mine owners by the following year. ${ }^{36}$ In 1832, mine owners objected to the growing strength of the unions and refused to 'bind' any man who was a member. New strikes began in March, and things escalated quickly. Families were evicted from their cottages, and by spring, more than eight thousand pitmen were on 
Fig. 6.10 Replica of Jobling's gibbet, South Shields Museum (Sarah Tarlow)

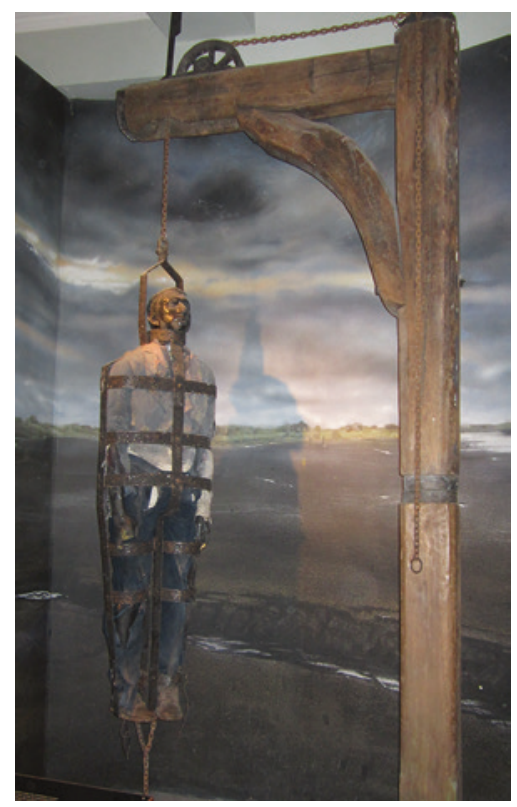

strike. Nearly the same number had returned to work and were supporting those on strike with pay contributions. As David Ridley has argued, this situation was more than a labour dispute: industrial unrest, a major cholera epidemic, and the parliamentary reform campaign of 1831-1832 made for a critical and acute state of crisis. There were assaults, riots, and a simmering unrest that threatened to boil over at any point. ${ }^{37}$ For this reason, Nicholas Fairles, Esq., a Magistrate of the county of Durham took up temporary residence at the Jarrow Colliery to be on hand to prevent further breaches of the peace. Fairles was, by all accounts, a well-respected elder member of the community. As Alan Marshall discovered, Fairles was energetically involved in upholding the law: he once ordered the seizure of 500 cakes and rolls having found them to be deficient in weight, and gave the confiscated bread to the poor. On another occasion, he intervened to prevent a medical man from procuring corpses from the Constable and the churchyard. ${ }^{38}$ Stern, smallish, septuagenarian Fairles was returning on a pony on the afternoon of 11 June 1832 when he met William Jobling, just past a turnpike on the road from Jarrow Colliery. 
On the day everything changed, William Jobling, pitman, husband to Isabella (née Turner), and father to several young children, was drinking. For a 30-year-old man who had likely begun working in the mines before the age of 10, this pursuit was something of a given. Jobling had been out of work since 5 April, and now some two months later, lacked the coin to pay his way. His solution was to linger by the road and ask passers-by to 'treat him with a quart of ale'. ${ }^{39}$ He met with some success because we know he was given a shilling by John Arthur Foster (of the Jarrow colliery) for this purpose. When Fairles rode by Turner's public house at about five o'clock, Jobling approached him, laid a hand on that of Fairles, and with good grace asked for money for a drink. Fairles refused, noting that the man-who was known to him-had appeared to have already had 'a sufficiency'. ${ }^{40}$ At this point, another man came up behind Fairles, took hold of his coat and dragged him from his horse.

Eyewitnesses saw two men setting upon the Magistrate and all three struggling on the ground. 'One of the men rested on Mr. Fairles, and struck him with a large stick, and the other held him down', and Mary Taylor and her aunt, Margaret Hall said they heard one of the men say 'kill him, kill him'. ${ }^{41}$ Taylor shouted at the men to be off, and the two assailants ran away. Fairles, badly injured and bleeding, was led away by the women to a nearby house.

His injuries were severe, but Fairles lived for another 10 days. Before he expired on 21 June, Fairles gave a statement on the attack. He named Jobling as the man who had held him down, and Ralph Armstrong, a pitman of Jarrow colliery, as the man who had attacked him from behind, and battered his head with stones and the heavy, horn stick Fairles was accustomed to carry. It didn't take long to locate Jobling, a man witnesses who spoke in his defence called quiet, harmless and inoffensive, 'a notorious coward' unlikely to engage in such an aggressive, violent act. ${ }^{42}$ Armstrong, on the other hand, never stood trial. $\mathrm{He}$ absconded after the attack, and at the time of Jobling's trial, Armstrong was still at large-despite hundreds of pounds offered as a reward for his apprehension. ${ }^{43}$ This pitman who had also been in the employ of the Jarrow Colliery, was 'about 44 Years of Age, 5 feet 9 inches high, stout made, Dark Complexion, Blue Eyes, large Mouth, large turned-up Nose and Brown Hair', ${ }^{44}$ and was never caught.

But for Jobling, there was no escape. Tried for murder during the Durham Assizes on 1 August 1832, Jobling's indictment charged that he was present and assisted Armstrong in murdering Fairles. ${ }^{45} \mathrm{He}$ pleaded 
not guilty. Witnesses were called, and testified to seeing Jobling stop Fairles' horse, to seeing him struggling on the ground with Armstrong and Fairles, and that both men had been seen running along the road leading to South Shields (where Jobling was apprehended), Armstrong with blood on his hands. ${ }^{46}$ The deposition made by Fairles himself was produced and stated that Jobling had held Fairles down with hands and knees while Armstrong struck the victim's head with stones. When Mr. Cobb, police officer for South Shields, produced Fairles' stick with blood visible on the end, the newspaper reported that 'Jobling changed colour' ${ }^{47}$ Jobling maintained his innocence, stating that he ran away when Armstrong pulled Fairles off his horse. The jury didn't take long to consult, and in just fifteen minutes returned their verdict: guilty.

Sentence was duly passed by Mr. Justice Parke. He warned Jobling to expect no reprieve. Parke attributed the 'want of moral principle' which allowed Jobling to stand by while a man was viciously attacked to the unions - the 'combinations' - which had been active in the labour disputes between pitmen and mine owners in the region. ${ }^{48}$ Parke called combinations 'injurious to the public interest and to those who are concerned in them' and in sentencing Jobling to a shameful death on the gallows, 'hoped to God it would be a warning to others'. ${ }^{49}$

But he didn't stop there. Aware that a new bill before parliament to discontinue dissection as a punishment for convicted murderers had probably already received Royal Assent, Parke kept to what remained of the Murder Act and sentenced Jobling to hang in chains and 'hoped the sight of it would have a due effect on the prisoner's companions' ${ }^{50}$ In accordance with the dictates of the Murder Act, the execution was scheduled for just two days later. On the platform, as he was about to be launched, 'a person near the scaffold cried out, "Farewell, Jobling", and he instantly turned his head in the direction whence the sound proceeded, which displaced the cord, and consequently protracted his sufferings, which continued some minutes' ${ }^{51}$ The gallows then the gibbet, erected on Jarrow Slake within sight of Jobling's wife's cottage, were guarded by soldiers. However, as soon as the guard was withdrawn, Jobling's remains were removed under cover of night. His corpse had swung in its cage for only about a month. There had been no order to bring down the body, as there was for James Cook (gibbeted shortly after Jobling in Leicester) whose gibbet was brought down by order of the Home Office after just three days. ${ }^{52}$ Whoever rescued Jobling's corpse from the gibbet on the night of 7 September 1832 put themselves at great risk: the crime of taking a body 
from a gibbet still carried a penalty of 7 years transportation. However, it seemed clear to those in the area that Jobling's fellow pitmen were unhappy with the harsh punishment meted out to their compatriot, and acted thus in 'service to his memory'. 53

And this memory lives on.

Today, songs, stories, poems and memorials tell us that Jobling was a man punished by the powerful as an example to his compatriots at the Jarrow collieries. His death and post-mortem punishment were intended as a shocking deterrent to labour organising in the nineteenth century. Jobling and his gibbet can be consumed, metaphorically, in the form of a beer called Jobling's Swinging Gibbet made by the Jarrow Brewery. Vincent Rea staged a comprehensive exhibition about Jobling and his post-mortem punishment in 1972 at the Bede Gallery that included artistic representations and a life-sized model/replica of Jobling's gibbet commissioned from artist Laurie Wheatley. The folk band The Whiskey Priests' song 'Farewell Jobling' commemorates Jobling's memory in music. $^{54}$

The myth of William Jobling, as martyr/murderer endures, but is, of course, unlikely to provide satisfactory answers to the complicated contexts and violent outcomes of both crime and punishment in this case. Though gibbeting as a punishment was intended to remove the comfort or certainty of a final earthly resting place from the condemned, in the case of Jobling this uncertainty is magnified because though his body was rescued, it has never been found. Today, a small stone memorial stands to remind those passing of Jobling. It was erected at the former site of the Gaslight public house where the body in its cage was rumoured to have been buried after it was 'rescued' from the gibbet. But this additional absence has not deterred those drawn to his story and its enduring meaning, nor does it seem likely to.

\section{Spence Broughton, 1792}

Spence Broughton is remembered by some as the last man gibbeted in England. ${ }^{55} \mathrm{He}$ wasn't, not by a long shot. ${ }^{56}$ However, Broughton is remembered and that is a much more remarkable feat considering that he died more than 200 years ago and achieved very little of note in his forty-six years. So why is he remembered? Primarily for what happened to his body after his death, and the years it spent on display as it mouldered, rotted and fell to pieces. 
Spence Broughton was executed on the gallows outside York Castle on 14 April 1792. He had been imprisoned for 6 months before his life ended at the end of a rope. Broughton had abandoned his wife and three children to spend his time gambling, but not before financially ruining his once-comfortable family. Born in Horbling near Falkingham, Lincolnshire, Broughton was a tall, well-made man. He was reputed to be from an honest and hardworking family, but was eloquently described in a small volume devoted to his life and crime as 'a degenerated plant from a good tree'. ${ }^{57}$ Gambling was his main pastime, and it is perhaps no surprise that he lost much more than he ever won. ${ }^{58}$ This behaviour put his family into severe financial difficulty, and Mrs. Broughton at last secured a separation.

Broughton particularly favoured cockfighting, races, and games of chance including E $\mathrm{O}$ tables (a game of chance related to roulette). He lost huge sums, and when personal and family funds ran dry, Broughton turned to theft to support his dissolute habits. In the company of John Oxley and Thomas Shaw, Broughton planned and carried out robberies of mail coaches. Shaw provided information and funds, Oxley converted bills found in the mail into cash, and Broughton took the lead in carrying out the thefts.

Oxley, Shaw and Broughton robbed the Rotherham Mail carried by a boy, George Leasley, on Attercliffe Common between Sheffield and Rotherham on the night of Saturday 29 January 1791. Leasley testified that a mile-and-a-half from Rotherham, he was stopped by two men whose faces he could not see who compelled him to leave the road, 'one tied his hands and fastened him to the hedge, whilst the other cut away the bag containing the letters, with which they made off.' 59 A foreign bill of exchange worth $£ 123$ was taken from the mail, with the help of a French dictionary the bill was exchanged successfully and Oxley 'decamped with all the proceeds except for $£ 10$ '. ${ }^{60}$ Broughton went after him and after some effort obtained $£ 40$ from Oxley. ${ }^{61}$ They then planned and executed the robbery of the Aylesbury Mail on 28 May 1791 but finding little of value, actually lost money on the venture. ${ }^{62}$ Finally, the trio planned to rob the Cambridge Mail in June 1791. This was the most successful of their efforts. Targeting the Cambridge Mail the day after the Newmarket races meant that the mail was packed with the bank bills of London's gentleman gamblers. As before, the boy carrying the mail was taken off the road into a field and tied to a post there. The robbers buried the Cambridge letters in a nearby field, and took 
from the mail thousands of pounds of bank bills, nearly $£ 5000$ of which Oxley successfully cashed in London at several establishments before the robbery became public knowledge. ${ }^{63}$

The malefactors were apprehended when on enquiring with the bankers, the bills were found to have been stolen from the Cambridge Mail, and Oxley was identified, pursued and taken in London. He claimed the bills belonged to Shaw, and directed the thief-takers to Shaw's lodgings, but on arrival found Broughton there and after a chase, apprehended him. Shaw was not long in following. The three were held in gaol and closely questioned. Shaw turned King's evidence, laying the blame on Oxley and Broughton. Oxley escaped from gaol in October 1791, and in the end, only Broughton stood trial. He was transported to York in January 1792, ${ }^{64}$ and at the Lent Assizes in York, 'indicted for feloniously assaulting George Leasley on the King's highway in the county of York, putting him in fear, and taking from his person the ROTHERHAM MAIL'. ${ }^{65}$ The trial only took two-and-a-half hours to find Broughton guilty, ${ }^{66}$ and despite his protestations that he was miles away when the crime took place Judge Buller immediately passed sentence of death.

To deter similar crimes, Judge Buller decreed that punishment should not end with execution, but rather that Broughton's body should hang in chains at the site of his crime. Executed on 14 April, the body was then taken from York to Attercliffe Common and in the small hours of Monday 16 April 1792, suspended on a gibbet near the Arrow Inn.

Certainly, Broughton was not the only highwayman gibbeted for his crimes. Though distinctly unbloody, the nature of his transgression threatened the security of property and movement of finance, which sat at the heart of the capitalist values on which the nation was built, and so warranted severe punishment in the eyes of the law. The public fascination with the image of the dashing highwayman during this period (and since) was also a risk to public order. Harsh punishment held the possibility of bursting the bubble of public approbation of such robbers. The post-mortem aspect of Broughton's punishment was specifically intended as a warning to others. For this, the grisly and highly visible nature of the suspension of Broughton's corpse on a gibbet should have been a good fit.

Instead, within hours of the erection of the gibbet post and before the body in its iron cage had been brought by cart to be hung up, the site of the gibbet of Spence Broughton attracted hundreds of people keen to see the spectacle. This is perhaps no surprise as newspapers noted the unusually high attendance at the execution. ${ }^{67}$ The publican of the Arrow, 
situated near Attercliffe Common, recalled that at eight o'clock in the evening, on the day after the execution (Sunday), 'the common was like a fair'. ${ }^{68}$ This man, George Drabble, was the one to lead the officials conveying Broughton's corpse to the site of the gibbet, some 200 yards from the Arrow. His assistance was rewarded by the incredible number of customers brought to the Arrow in the weeks and months that followed, drawn to witness the gibbet. One local recollection described the scene: 'On the first Sunday after he was gibbeted, all the road through Attercliffe was one mass of people, going to and from the gibbet. Many remarked they never saw so many people in their lives, and wondered where they came from, for it beat Sheffield fair, and seemed as if they never would give over coming. ${ }^{69}$ It is difficult to identify the crowd's reaction to witnessing Broughton's gibbet, but it seems to have served more as public entertainment than a solemn lesson.

Broughton's gibbet remained in place for more than 36 years. As late as 1828, it was still possible to see 'his skull, and a few bones and shreds of clothing, which had survived the storm and stress of the weather. ${ }^{70}$ A Sheffield local, Dr Sorby, recalled that the gibbet had stood on land belonging to his father, who was the one who took the structure down 'owing to the inconvenience of people coming to see it'. ${ }^{71}$ That the gibbet with its mostly empty cage continued to draw curious onlookers nearly four decades after Broughton's corpse was suspended there is telling: these visitors included many not even born at the time of Broughton's execution, and for whom the gibbet itself was of much more interest than the individual for whom it had been built or his crime. In fact, in 1867 'Many hundreds of persons' came to see the excavated remains of Broughton's gibbet post ${ }^{72}$ - a piece about four-and-ahalf feet long and 18 inches square black with age-which was unearthed during excavations for new houses in Clifton Street on what was once Attercliffe Common.

Today, Broughton's story is most prominently, and fictitiously, visible in the form of the advertising for the Noose and Gibbet Inn, located near the site of Broughton's gibbet (Fig. 6.11). The Inn proclaims Broughton to be the last man hanged in England (which he clearly was not) and sports a 'replica' gibbet complete with a mannequin to greet those passing in front of the building. This is no historically accurate reproduction, the pretend irons being of the 'bird cage' variety. So what does this mean for the story of Spence Broughton and his life and crimes? Perhaps it is fitting that just as the grisly spectacle of the gibbeted 


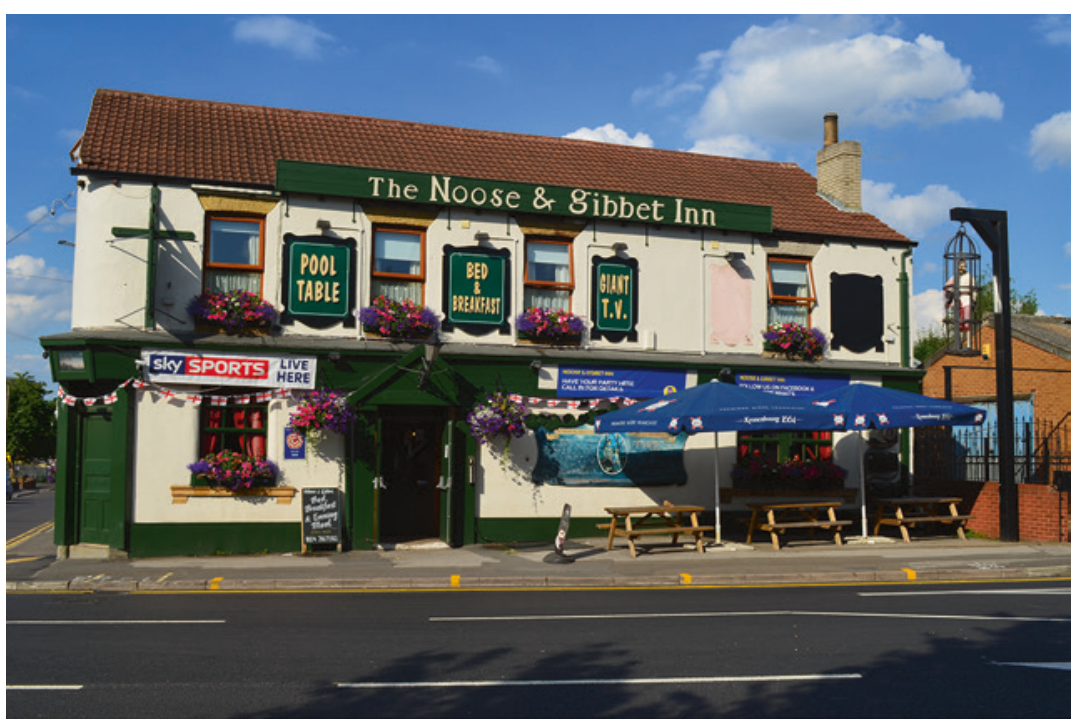

Fig. 6.11 The Noose and Gibbet Inn, Sheffield, exploits its proximity to the place where Spence Broughton was gibbeted with a wholly inauthentic recreated gibbet (Tom Maskill)

body drew visitors and served as a sort of entertainment, so today the Noose and Gibbet Inn, and its sensational representation still draw in the punters.

\section{Marie-Josephte Corriveau, 1763}

We know that no women were gibbeted in the eighteenth and nineteenth centuries in Britain. Invariably, women convicted of murder were punished with hanging and dissection or, in the event that the murder was categorised as petty treason (the killing of a male superior such as a master, father, or husband), up to the end of the eighteenth century by strangulation then by burning at the stake. ${ }^{73}$ We remain curious as to why anatomisation and dissection, involving as it did the exposure of the opened and at least semi-nude body to public view, were somehow considered a more appropriate treatment of the bodies of female murderers than their display fully clothed in the gibbet. Whatever the reasons, the result is clear: under the Murder Act, no women were hung in chains. 


\section{Except one.}

In the eighteenth century, Britain engaged in active and energetic colonisation of places and peoples around the globe. Less than two decades before the American Revolution, the British were involved in a contest with another and much more established colonial force in the eastern part of North America. In 1759, General Wolfe defeated le Général Montcalm at the Plaines d'Abraham, and ended King Louis XV of France's control of Nouvelle France. ${ }^{74}$ This region, which today is encompassed by the Canadian province of Québec, had been settled since the early seventeenth century as a French Catholic colony. The Canadiens, as the inhabitants were known, were an agricultural people who lived according to the seigneurial system of land tenure and feudal agricultural practice. Before the British conquest, the French king kept tight controls on Nouvelle France, including prohibiting the establishment of a domestic press in order to head off the possibility of the rise or spread of rebellious ideas or actions. The English began their control of Nouvelle France following Wolfe's victory but it was not until the autumn of 1763 that civil authority was established for the province of Québec under the terms of King George III's Royal Proclamation of 7 October 1763. For the years between conquest and the advent of civil government under the British, the colony operated under military law and General James Murray served as Governor. His was the highest authority in the province and he had responsibility for confirming all sentences passed by courts martial. During this interim period, a death occurred, a court martial followed, and a woman was convicted of murder. Her name was Marie-Josephte Corriveau and her legend is inseparable from the cage in which her corpse was displayed two hundred and fifty years ago.

Marie-Josephte Corriveau was born in Saint-Vallier near Québec and baptised on 14 May 1733. She was the daughter of farmer Joseph Corriveau and Marie-Françoise Bolduc. First married in 1749 to Charles Boucher, also a farmer, she had three children before her husband died in 1760. She married again in July 1761 to another farmer, one Louis Dodier. Dodier's corpse was discovered in the early morning of 27 January 1763 in his stable. It appeared that he died at some point in the night as a result of several severe wounds to the face and head. Whether the fatal wounds had been caused by a horse, or a sharp instrument was a matter of some debate. The day before the incident, Joseph Corriveau had complained about his son-in-law during a visit to the local 
priest and it was said that Marie-Josephte had asked her father to beat her husband. We have access to the detail of the initial court martial, at which Joseph Corriveau was tried for murder and Marie-Josephte was tried as an accomplice, thanks to the preservation work of J.M. Lemoine who was president of the literary and historical society of Québec in the late nineteenth century. ${ }^{75}$ The transcript of that court martial reveals a meticulous process of investigation, and includes testimony from those who had attended the scene after the body was discovered, members of the Corriveau family, people of the neighbourhood, and details from a coroner's inquest. The first trial began on 29 March 1763 and ended on 9 April. The conclusion was that Joseph Corriveau was convicted of murder and sentenced to execution, and that Marie-Josephte was found guilty of being an accomplice to the crime and sentenced to public whippings and to be branded. However, shortly afterward, Joseph made a confession. He avowed that it was actually his daughter who had committed the crime. A second court martial was convened. Joseph was proclaimed innocent, and once she had made a confession, Marie-Josephte was convicted of the murder of her husband. She was sentenced to death by hanging and to additional post-mortem punishment in line with the terms of the Murder Act.

She was hanged at Québec on 18 April 1763. Shortly after, the corpse was encased in a purpose-built cage that followed the general form of cages constructed in Britain. The body of Mary-Josephte was gibbeted for five weeks at a crossroads in St. Joseph, Point Levy, Québec before being removed and taken away for burial at a nearby churchyard, whose specific location was not made public, still encased in the gibbet irons.

In 1849, workers digging behind the church of Saint-Joseph-ofBellechasse as part of renovation efforts discovered an iron body-shaped cage still containing a few bones. It was recognised immediately as the gibbet cage of Marie-Josephte Corriveau. The gibbet cage of 'La Corriveau', as she came to be known, became an immediate object of interest, and was sold to Barnum's Circus in New York who took it on tour to cities including Montreal, New York, and Boston where people paid to see this ghoulish curiosity. It is reported that the cage was presented by David P. Kimball to the Essex Institute in Salem, Massachusetts in 1855 where it was kept in their collections of scientific and historical materials until the early twenty-first century. ${ }^{76}$ In 2013, however, the cage again became an object of intense interest as it was 'rediscovered' by Québécois researchers. After tests carried out 
on the metal of the cage and historical investigation, in 2015 'la cage de la Corriveau' was confirmed to be authentic, and was repatriated to Québec as an object of significant historical and cultural value.

But what made this artefact so special and so significant? In the years after her death and post-mortem punishment, the story of MarieJosephte grew, twisted and transformed. As Luc Lacourcière noted in his seminal article on this history and phenomenon in 1969, scarcely a year has gone by since 1763 that this story, and the figure at the centre of it, have not been the subject of new literary and artistic representations. ${ }^{77}$ Indeed, because of the indelible connection between woman and crime cemented by the cage that was so integral to her spectacular public post-mortem punishment, La Corriveau became one of the key figures not only in Québécois patrimoine (heritage), but in Canadian folklore more broadly. To call her story a 'legend' is by no means an overstatement. Marie-Josephte's conviction for the murder of her husband and grisly gibbeting gave rise to her being recast as an evil woman who murdered not only her second husband, but her first, and as many as five others. In the vilification that followed her punishment, she became not only a notorious murderess, but also a sorceress and a malignant spirit set on tormenting the living.

In the context of our research, Marie-Josephte is remarkable not only for what her story became, that potent legend of La Corriveau, but for the way her post-mortem punishment stands in such stark contrast to that meted out to convicted female murderers in Britain. So, why was Marie-Josephte Corriveau tried, convicted and punished in this way? That she was tried by a court martial instead of a civil process was recognised as an error by Governor Murray, who nonetheless noted that in the absence of other established structures during the interim period between formal French and British rule, he had followed a precedent set in a similar situation in Montreal two years earlier. ${ }^{78}$ That she was sentenced to post-mortem punishment on the gibbet in addition to execution on the gallows also followed the precedent set in the 1761 case. However, if she was sentenced under British law, why was she not sentenced to burning, as would have been the appropriate punishment for a woman convicted of petty treason-and being found guilty of murdering her husband, Marie-Josephte would certainly have met the criteria for this specific crime. But if, as it seems, she was sentenced according to the Murder Act, why not anatomisation and dissection as would have been the norm had she been in Britain? It is likely few facilities existed for such 
a course of action, which may have impacted the decision. However, there is also the issue of when the murder and punishment took place with relation to the political situation. Both occurred before the instigation of civil rule by the British in what had been Nouvelle France, and the punishment of Canadienne (French Settler) Marie-Josephte by a British court martial suggests an effort by British authorities to use the post-mortem punishment of convicted murderers as an example to others who may have sought to instigate unrest or challenge British rule. It is possible that in her case, the analogy between treason and petty treason meant that husband-murder stood in for political insurrection, thus making such a harsh and ostentatious punishment seem appropriate.

We know that the British carried gibbeting as a post-mortem punishment as part of its colonising efforts not only to Canada, but also to America, Australia, New Zealand and India. When used to punish white British overseas subjects, gibbeting followed the form used by the civil authorities in Britain. However, the use of the gibbet to punish enslaved African people-men and women-particularly in the plantation colonies, was much more brutal and violent. In Antigua, six enslaved African individuals were gibbeted following an uprising in 1736. They were gibbeted alive and condemned to hang in chains to die of thirst, hunger and exposure. ${ }^{79}$ In Jamaica, gibbeting alive was one of a suite of horrific punishments used by the white planter class to terrify and control enslaved African people. ${ }^{80}$ Two men, Fortune and Kingston, were gibbeted alive in 1760 in Kingston, Jamaica. These enslaved African individuals were captured as ringleaders of the violent St Mary Rebellion against the white planter class and were gibbeted alive at one of the thoroughfares of the capital. ${ }^{81}$ A sketch from that decade depicts a gruesome double gibbet on Kingston's main parade. ${ }^{82}$ The gibbet was also used to punish enslaved black people in colonial America, such as in the case of one man 'hung alive in chains in the town' in New York City following a rebellion of enslaved African people. ${ }^{83}$

Yet Marie-Josephte Corriveau remains the only (white) woman we know of hung in chains under the Murder Act. For other subjects whose bodies were gibbeted in the British world, infamy is likely a more appropriate way to refer to their posthumous and in some cases, long enduring renown than the status of legend rightfully accorded to MarieJosephte Corriveau. In Britain, ghost stories around gibbets are surprisingly rare, and certainly none approaches the recognition and notoriety of La Corriveau as she continues to be known in literature, legend and 
contemporary renderings. But more appropriately, we argue, that name refers to the union of a woman accused and convicted of a crime and the cage that played a key role in her post-mortem punishment. Indeed, without the gibbet, Marie-Josephte Corriveau would never have been transformed into the legendary voracious man-murderer, malignant spirit and tragic dark figure still known today.

\section{The Gibbet Today: Enduring And Apocryphal}

We are not the first, nor will we be the last to tell the stories of Jobling, Broughton, and Corriveau. Our tellings are intimately related to the context in which these stories are told here: in relationship with our focus on the criminal corpse in eighteenth- and nineteenth-century Britain. As John Lutz has said, all historical sources are partial, in both senses of the word. ${ }^{84}$ Our tellings are similarly partial. We tell these stories here, together and assembled in this way, to move from historical summary to more individual detail, and to try to create a view into the historical use of the gibbet that may allow us to connect our own ideas, assumptions, and feelings with an event and experience that is otherwise alien.

Today, the gibbet persists in contemporary representations, artefacts and stories. Some gibbet sites are commemorated or maintained, the most well known of these being Combe Gibbet, Winter's Gibbet and Caxton Gibbet which still sport replicas of their original posts (Fig. 6.12). ${ }^{85}$ These sites still attract the public-for example, the Combe Gibbet to Overton annual 16-mile cross-country race uses the gibbet site as a key place marker as well as the name of the event. Gibbet artefacts are popular items in the local museums that house them, and the ghoulish nature of their history appeals to a wide range of ages and interests.

The gibbet is also with us in more fanciful forms. Birdcage style gibbet Halloween decorations are sold in both the United Kingdom and North America, and similar versions can be found in various macabre entertainments, such as the popular London Dungeon experience. In these contemporary forms, the gibbet has been safely contained in museum spaces, made campy displays for macabre holidays, or has even been converted into voluntary erotic indulgence by some with a sexual taste for punishment, but in all cases the gibbet retains its entertainment value and dark fascination for those not subjected to its historical and actual ends. 
(a)

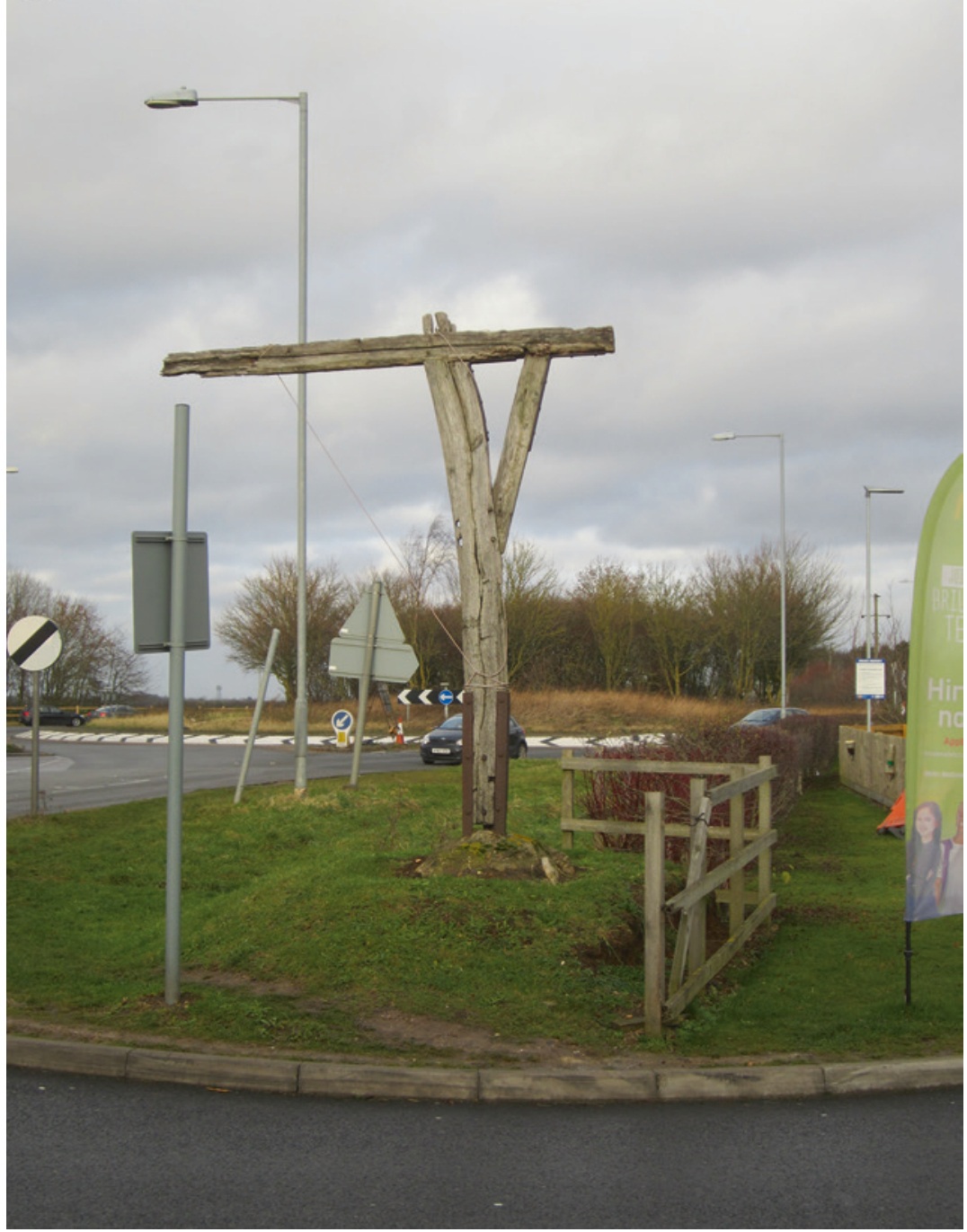

Fig. 6.12 (continued) 


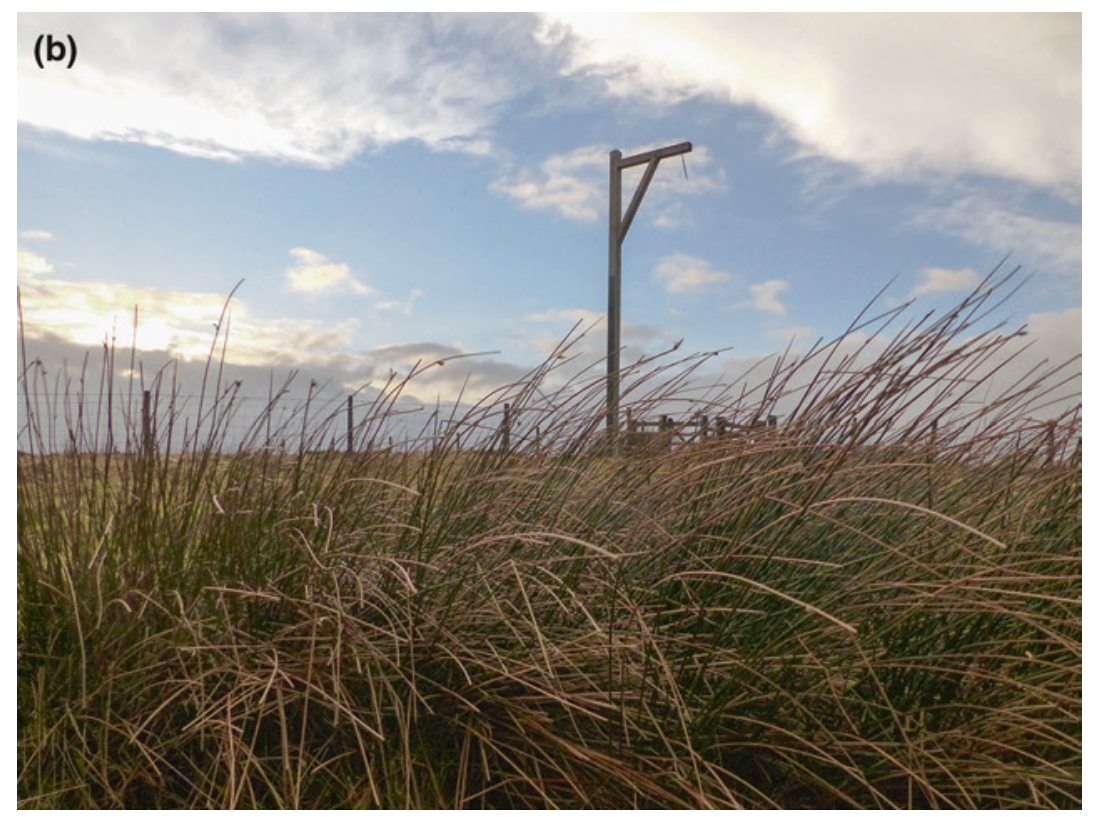

Fig. 6.12 a Caxton gibbet (Sarah Tarlow) and b Winter's gibbet (Patrick Low). Both gibbets have been curated, restored and replaced to enable their continued function as local landmarks

\section{Notes}

1. See, Tarlow, S. (2017), The Golden and Ghoulish Age of the Gibbet in Britain (Palgrave Macmillan).

2. In eighteenth- and nineteenth-century Britain, gibbeting was a punishment used by civil and military authorities, and the practice shows some variation between these two groups. The Admiralty used gibbeting to punish piracy and mutiny in a variety of traditional locations usually located along a shoreline and sometimes also reused gibbet cages/chains. Gibbeting by the civil authorities differed in terms of gibbet technology.

3. See, Robin Hood: Prince of Thieves (1991) [film], dir. by Kevin Reynolds (USA: Warner Bros.); Pirates of the Caribbean: The Curse of the Black Pearl (2003) [film], dir. by Gore Verbinski (Walt Disney Pictures).

4. Pratchett mentions gibbets in at least three Discworld novels. These include Nightwatch (2011), The Fifth Elephant (1999), and Feet of Clay (1996). It is worth mentioning that in the Discworld, gibbets are constructed and function in a much more historically accurate manner than 
in most other fictional contexts. Their reception also follows historical example. In Feet of Clay, Pratchett writes: 'At the end of Nonesuch Street was a gibbet, where wrongdoers-or, at least, people found guilty of wrongdoing-had been hung to twist gently in the wind as examples of just retribution and, as the elements took their toll, basic anatomy as well. Once, parties of children were brought there by their parents to learn by dreadful example of the snares and perils that await the criminal, the outlaw and those who happen to be in the wrong place at the wrong time, and they would see the terrible wreckage creaking on its chain and listen to the stern imprecations and then usually (this being Ankh-Morpork) would say "Wow! Brilliant!" and use the corpse as a swing.'

5. See, Willow (1988) [film], dir. by Ron Howard (USA: Metro-GoldwynMayer).

6. This is discussed further below in the context of the social discourse around gibbeting.

7. See, Tarlow, S. (2017), The Golden and Ghoulish Age of the Gibbet in Britain (Palgrave Macmillan).

8. This differentiation draws on the work of Ellul, J. (1954), La Technique: L'enjeu du siècle (Paris: Armand Collin).

9. For a discussion of the criteria by which gibbets were selected, see for example, Tarlow, S. and Dyndor, Z. (2015), 'The Landscape of the Gibbet', Landscape History, Vol. 36, Issue 1, 71-88; and for a consideration of the technical and design features of the gibbet cage, see, Tarlow, S. (2014), 'The Technology of the Gibbet', International Journal of Historical Archaeology, Vol. 18, Issue 4, 668-699.

10. The Sheriff's Cravings are records of expense claims submitted to the Treasury by each county's sheriff for the costs incurred in the punishment of all assize convicts. They can be accessed at The National Archives, London, Sheriffs' Cravings, T 64/262, T 90/148-66, Sheriffs' Assize Calendars, E 389/242-8.

11. This previously underexploited source of evidence was discovered by Richard Ward, and examined in, Ward, R. and King, P. (2015), 'Rethinking the Bloody Code in Eighteenth-Century Britain: Capital Punishment at the Centre and on the Periphery', Past of Present, Vol. 228, Issue 1, 159-205.

12. For a list of existing gibbet cages in Britain, see, Tarlow, S. (2014), 'The Technology of the Gibbet', International Journal of Historical Archaeology, Vol. 18, Issue 4, 668-699, list at page 684. We should note that not all of these cages date from the period of the Murder Act, but all were used by the civil authorities (not the Admiralty), except possibly for the one owned by Winchester Museums. The small sample size makes consideration of cages from beyond the period considered in this chapter necessary. 
13. Much about the gibbet has relied on secondary literature and repeated some things as 'facts' which are otherwise unsubstantiated. This primary source investigation is unprecedented in this area.

14. See for example the case of Spence Broughton at the end of this chapter. And on the connection between crime or individual and site of punishment see Stephen Poole (2015), "“For the Benefit of Example”: Processing the Condemned to the Scene of Their Crime in England, 1720-1830', in Ward, R. ed., A Global History of Execution and the Criminal Corpse (Basingstoke: Palgrave); Tarlow, S. and Dyndor, Z. (2015), 'The Landscape of the Gibbet', Landscape History, Vol. 36, Issue 1, 71-88.

15. Though many place names including the word 'gibbet' still exist today across Britain, it is worth noting that most of these relate to medieval sites of execution.

16. See, Andrews, W. (1899), Bygone Punishments (London: W. Andrews \& Company), p. 63.

17. Sleath, S. and Ovens, R. (2007), 'Lower Hambleton in 1797', in Ovens, R. and Sleath, S. (eds.), The Heritage of Rutland Water (Rutland Record Series Number 5) (Oakham: Rutland Local History and Record Society), pp. 193-209.

18. A broken socket stone at Gonerby Hill Foot, Lincolnshire, is believed locally to have supported a gibbet at one time (http://www.lincstothepast.com/photograph/290331.record?pt=S).

19. See, Tarlow, S. (2017), The Golden and Ghoulish Age of the Gibbet in Britain (Palgrave Macmillan).

20. See, Tarlow, S. (2014), 'The Technology of the Gibbet', International Journal of Historical Archaeology, Vol. 18, Issue 4, 668-699.

21. One of the most well-known sources to make this claim is Hartshorne, A. (1893), Hanging in Chains (New York: Cassel Publishing Company).

22. London Chronicle, August 5-8, 1775, issue 2912.

23. See, Tarlow, S. and Dyndor, Z. (2015), 'The Landscape of the Gibbet', Landscape History, Vol. 36, Issue 1, 71-88, quote at p. 73.

24. See, Tarlow, S. and Dyndor, Z. (2015), 'The Landscape of the Gibbet', Landscape History, Vol. 36, Issue 1, 71-88.

25. As Peter King has found, no female murderers were gibbeted during the life of the Murder Act, and none of the fifty-five individuals convicted of property crimes and sentenced to hang in chains during the same period were women. King quotes noted eighteenth-century jurist William Blackstone who wrote 'the decency due to the sex forbids the exposing ... their bodies'. King goes on to point out that as women's corpses were sent for public anatomisation and dissection, the thinking behind this gendered policy remains unclear. Peter King, Punishing the Criminal Corpse 1700-1840: Aggravated Forms of the Death Penalty in England (Palgrave, in press), chapter 3, p. 14. Quoting William, Blackstone, Commentaries on the Laws of England, 2, 18th London ed. 
(New York: Collins and Hannay, 1832), as quoted in Simon Devereaux, (2009, February), 'Recasting the Theatre of Execution: The Abolition of the Tyburn Ritual,' Past \& Present, Vol. 202, pp. 127-174, p. 77.

26. See, Naish, C. (1991), Death Comes to the Maiden: Sex and Execution 1431-1933 (London: Routledge).

27. The law at the time differentiated between 'petty treason'-betrayal of authority, as in a worker or servant betraying their employer-and 'grand treason' which is closer to the definition common today of attempting to undermine the state.

28. See, Tarlow, S. (2017), The Golden and Ghoulish Age of the Gibbet in Britain (Palgrave Macmillan).

29. Not that such a 'metric' is possible anyway; it's certainly not useful to or for us to try and create a hierarchy of horror against which to test a hypothesis.

30. In 1823, an act of Parliament authorised the transportation of British convicts to any colony designated by the Crown. This gave rise to transportation of English and Irish convicts in particular, to places like Bermuda where they were used for projects in support of imperial expansion. For accessible and comprehensive information on British convict transportation and the wider global context of this punishment, see the excellent outputs of Clare Anderson's The Carceral Archipelago, in particular her project website ConvictVoyages.org.

31. This is the narrative explored by Foucault, in Discipline and Punish, and Ignatieff, in A Just Measure of Pain. See also Markus, T. (1993), Buildings and Power (London: Routledge).

32. See for example, Rusc he, G. and Kirchheimer, O. (1939), Punishment and Social Structure (New York: Columbia University Press); Ignatieff, M. (1978), A Just Measure of Pain: The Penitentiary in the Industrial Revolution, 1750-1850 (London: Macmillan); Foucault, M. (1977), Discipline and Punish: The Birth of the Prison (Harmondsworth: Penguin).

33. See, Vaughan, B. (2000), 'The Civilizing Process and the Janus-Face of Modern Punishment', Theoretical Criminology, Vol. 4, Issue 1, 71-91, quote at p. 74 .

34. See, Tarlow, S. (2017), The Golden and Ghoulish Age of the Gibbet in Britain (Palgrave Macmillan).

35. See, Fielding, S. (2013), Hanged at Durbam [ebook] (The History Press), Appendix II. Available at https://books.google.co.uk/ books?id=WPo6AwAAQBAJ\&pg=PT203\&lpg=PT203\&dq=william + jobling + hanged + date \&source $=$ bl\&ots $=$ MMb5 GmM6Wg\&sig $=\nwarrow$ lVAe2 NiOmRu2hPtkSgAc4byXPk0\&hl=en\&sa=X\&ved=0ahUKEwiThY_SpYfNAhVPF8AKHdS5DU8Q6AEIWDAL\#v=onepage \&q= jobling\&f=false (Accessed 26 April 2017).

36. Tyne Mercury, 5 June, 22 and 29 May (1932), from, Ridley, D. (1994), Political and Industrial Crisis: The Experience of the Tyne and Wear 
Pitmen, 1831-1832, Durham theses, Durham University, p. 238. Available at Durham E-Theses Online: http://etheses.dur.ac.uk/5366/ (Accessed 26 April 2017).

37. See, Ridley, D. (1994), Political and Industrial Crisis: The Experience of the Tyne and Wear Pitmen, 1831-1832, Durham theses, Durham University, p. 238. Available at Durham E-Theses Online: http://etheses.dur.ac.uk/5366/(Accessed 26 April 2017).

38. Marshall, A. (2009), The Death of Nicholas Fairles: Law and Community in South Shields, 1832 (North East England History Institute).

39. The Morning Chronicle (London, England), Saturday 4 August 1832, p. 4.

40. NA HO 44/29, fo. 118. Deposition of Nicholas Fairles.

41. The Morning Chronicle (London, England), Saturday 4 August 1832, p. 4.

42. Ibid.

43. $£ 100$ was offered by the Vestry of St. Hild's Chapel, South Shields and a further $£ 300$ was offered by the government. The Newcastle Journal (Newcastle-Upon-Tyne, England), Saturday 4 August 1832, Issue 13, p. 3. From database British newspapers 1600-1950.

44. The Newcastle Journal (Newcastle-Upon-Tyne, England), Saturday 22 September 1832, Issue 20, p. 1. From database British newspapers 1600-1950.

45. The Morning Chronicle (London England), Saturday 4 August 1832.

46. Ibid.

47. The Morning Chronicle (London, England), Saturday 4 August 1834.

48. The Morning Chronicle (London England), Saturday 4 August 1832.

49. Ibid.

50. Ibid., p. 4.

51. 'Execution of William Jobling for the Murder of Mr. Fairles', Times (London, England), 6 August 1832, p. 5.

52. Related in the Newgate Calendar, 'JAMES COOK, Executed 10th of August, 1832, for the Murder of Mr. Paas, whose Remains he attempted to destroy by Fire'. Available at http://www.exclassics.com/newgate/ ng614.htm (Accessed 26 April 2017).

53. See, Pelham, C. (1841), The Chronicles of Crime, or the New Newgate Calendar (London: Printed for Thomas Tegg).

54. Whiskey Priests (1996), 'Farewell Jobling' [song], on Life's Tapestry [alb.] (Whiskey Priests).

55. See for example, Hindle, R. (2012), The Purging of Spence Broughton, A Highwayman. Available at: https://spencebroughton.wordpress.com/ essays / (Accessed 7 June 2017).

56. See, Tarlow, S. (2014), 'The Technology of the Gibbet', International Journal of Historical Archaeology, Vol. 18, Issue 4, 668-699.

57. See, The Life and Trial of the Unfortunate Spence Broughton (1792), (printed by John Drury, 3rd edition), p. 10. 
58. Ibid.

59. 'News' Leeds Intelligencer (Leeds, England), 2 April 1792, p. 3.

60. See, The True and Illustrated Chronicles of the Last Man Gibbeted in Yorkshire (1900) (reprinted by January Books), p. 2.

61. Ibid.

62. Lloyd's Evening Post (London, England), October 17-19, 1791, Issue 5352. Public-office, Bow-street Mail-Robbers, \&c.

63. Ibid.

64. 'News', Leeds Intelligencer (Leeds, England), 23 January 1792: 3.

65. See, The Life and Trial of the Unfortunate Spence Broughton (1792), (printed by John Drury, 3rd edition), p. 3.

66. 'News', St. James's Chronicle or the British Evening Post (London, England), March 24-27, 1792.

67. 'France', Chester Chronicle [Chester, England] 20 April 1792: 2.

68. Criminal Chronology of York Castle by William Knipe p. 125.

69. Hester, G. 28 January 1873, Sheffield Independent (Sheffield, England), 31 January 1873, Issue 5214, p. 4.

70. See, The True and Illustrated Chronicles of the Last Man Gibbeted in Yorkshire (1900) (reprinted by January Books), quote at p. 2.

71. Sheffield Independent (Sheffield, England), 4 March 1896, Issue 12931, p. 8.

72. Stamford Mercury (Stamford, England), 10 May 1867, Issue 8977, p. 3.

73. See, King, P. (2006), Crime and Law in England, 1750-1840 (Cambridge: Cambridge University Press). As King explains, throughout the eighteenth century, this punishment involved death before burning. This was also a punishment meted out against female coiners. Burning of women declined as a practice in eighteenth-century Britain, and was formally abolished in 1790 .

74. This battle was part of the larger French and Indian War (1754-1763) between England and France in North America, which in turn was part of the larger, global Seven Years War between those two imperial powers during the same period.

75. Bibliothèque et Archives nationales (BAnQ), Québec P1000 S3 D453, 1960-01-008/104.

76. The Essex Institute was succeeded by the Peabody Essex Museum in 1992, and the institution is considered one of the oldest continually operating museums in the United States.

77. See, Luc Lacoursiere, C.C. (1969), 'Le destin posthume de la Corriveau', Les Cabiers des Dix, Numéro 34, 239-271.

78. For a key article on the subject see, Luc Lacourcière C.C. (1973), 'Présence de la Corriveau', Les Cahiers des dix, Numéro 38, 229-264. The precedent-setting case was that of the 1761 conviction of Saint-Jean (also known as Saint-Paul) for a quadruple murder in Saint-Françoisde-Sales (Quebec) who was also gibbeted for his crimes. For more 
information see, Trudel, M. (1999), Le régime militaire et la disparition de la Nouvelle-France, 1759-1764 (Québec: Les Editions Fides).

79. Eighty-eight enslaved African people were put to death by the Antigua planters. Of these, 5 were broken on the wheel, 6 gibbeted alive, and 77 burned alive. See, 'America and West Indies: May 1737 16-31', in Davies, K.G. ed. (1963), Calendar of State Papers Colonial, America and West Indies: Volume 43, 1737 (London), pp. 155-173. Available at British History Online http://www.british-history.ac.uk/cal-state-papers/colonial/america-west-indies/vol43/ppl55-173 (Accessed 17 January 2017).

80. Burnard, T. (2004), Mastery, Tyranny, and Desire: Thomas Thistlewood and His Slaves in the Anglo-Jamaican World (Chapel Hill: University of North Carolina Press).

81. Institute of Jamaica, The Gleaner, 7 October, 2010. Available at http:// jamaica-gleaner.com/gleaner/20101007/news/news7.html (Accessed 19 April 2017).

82. Pierre Eugène du Simitière, untitled Jamaican scene, ca. 1760s. Ink on paper, $8 \times 13$ in. $(20 \times 30 \mathrm{~cm})$. The Library Company of Philadelphia. In Louis Nelson, Architecture and Empire in Jamaica, New Haven, Yale University Press, 2016, p. 127.

83. Letter of Governor Robert Hunter to the Lords of Trade, in O'Callaghan, E.B. ed. (1855), Documents Relative to the Colonial History of the State of New York (Albany, V, 1707-1733), pp. 341-342.

84. See, Lutz, J. (2008), Maguk: A New History of Aboriginal-White Relations (Vancouver: UBC Press).

85. See, Tarlow, S. and Dyndor, Z. (2015), 'The Landscape of the Gibbet', Landscape History, Vol. 36, Issue 1, 71-88.

Open Access This chapter is licensed under the terms of the Creative Commons Attribution 4.0 International License (http://creativecommons.org/licenses/ by $/ 4.0 /$ ), which permits use, sharing, adaptation, distribution and reproduction in any medium or format, as long as you give appropriate credit to the original author(s) and the source, provide a link to the Creative Commons license and indicate if changes were made.

The images or other third party material in this chapter are included in the chapter's Creative Commons license, unless indicated otherwise in a credit line to the material. If material is not included in the chapter's Creative Commons license and your intended use is not permitted by statutory regulation or exceeds the permitted use, you will need to obtain permission directly from the copyright holder.

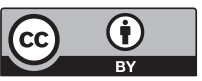

